\title{
ENGINEERING STUDY \\ DEVELOPMENT AND DETERMINATION OF A SINGLE-SHELL TANK INTERIM STABILIZATION PUMPING STRATEGY
}

\author{
Prepared for \\ Westinghouse Hanford Company \\ April 1995 \\ For the U.S. Department of Energy \\ Contract DE-AC06-93RL12359 \\ Prepared by \\ ICF Kaiser Hanford Company \\ Richland, Washington
}

ER4919ES, Rev. 2

\section{ICF Kaiser Hanford Company}




\section{DISCLAIMER}

This report was prepared as an account of work sponsored by an agency of the United States Government. Neither the United States Government nor any agency thereof, nor any of their employees, make any warranty, express or implied, or assumes any legal liability or responsibility for the accuracy, completeness, or usefuiness of any information, apparatus, product, or process disclosed, or represents that its use would not infringe privately owned rights. Reference herein to any specific commercial product, process, or service by trade name, trademark, manufacturer, or otherwise does not necessarily constitute or imply its endorsement, recommendation, or favoring by the United States Government or any agency thereof. The views and opinions of authors expressed herein do not necessarily state or reflect those of the United States Government or any agency thereof. 


\section{DISCLAIMER}

Portions of this document may be illegible in electronic image products. Images are produced from the best available original document. 
WHC-SD-WM-ES-345, REV. 0

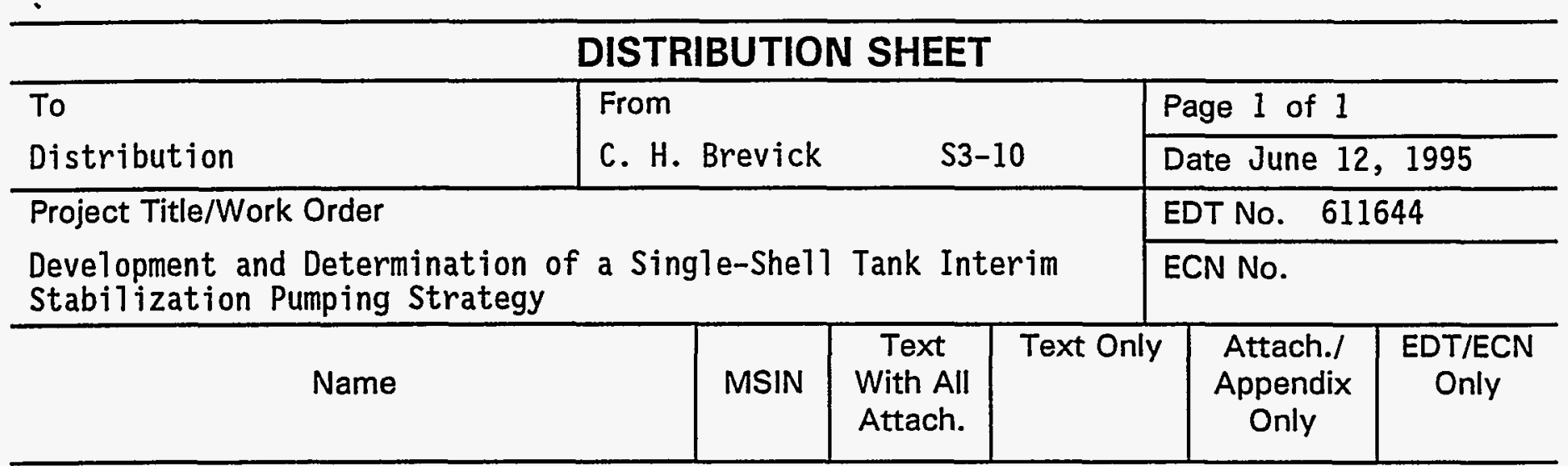

Westinghouse Hanford Company
D. B. Engelman
A. $K$ Dasqupta
R1-49
S3-28
RI-49
C. E. Jenkins
D. C. Krahn
J. L. Lee
H4-68
R2-50
R2-54
R2-54
R. E. Raymond
H4-65
G. W. Ryan
R. R. Stickney
TFIC (Tank Farm Information Center)
R1-49
$\mathrm{R} 1-20$
L8-04
A3-36

$X$
$X$
$X$
$X$
$X$
$X$
$X$
$X$
$X$
$X$
$X(2)$
$X(2)$
OSTI

$\begin{array}{ll}\text { S3-10 } & X \\ \text { S3-10 } & X \\ \text { S3-10 } & X \\ \text { R2-80 } & X \\ \text { E6-63 } & 0 \\ \text { S3-10 } & X\end{array}$

L. J. Garvin

S. L. Kujak

D. T. Vladimiroff

ICF KH Publications

ICF KH Doc Control

S3-10

$\mathrm{X}$

$\mathrm{X}$

$\mathrm{X}$

Pacific Northwest Laboratory
J. B. Colson
K5-10
J. W. Johnston
K3-59
$x$
$x$

Department of Energy - Rich1 and Operations
G. E. Bishop
S7-54
S7-54
$X$
$X$ 


\begin{tabular}{|l|l|}
\hline $\begin{array}{l}\text { 2. TO: (Receiving Organization) } \\
\text { DISTRIBUTION }\end{array}$ & $\begin{array}{l}\text { 3. From: (Originating Organization) } \\
\text { TWRS }\end{array}$ \\
\hline 5. Proj./Prog./Dept./Div.: & $\begin{array}{l}\text { 6. Cog. Engr.: } \\
\text { ER4919 }\end{array}$ \\
\hline $\begin{array}{l}\text { 8. originator Remarks: } \\
\text { This document describes development and determination of a }\end{array}$ \\
single-she11 tank interim stabilization pumping strategy.
\end{tabular}

11. Receiver Remarks:

\begin{tabular}{l} 
4. Related EDT No.: \\
$\begin{array}{c}\text { 7. Purchase Order No.: } \\
\text { 9. Equip./Component No.: } \\
\text { N/A }\end{array}$ \\
\hline $\begin{array}{c}\text { 10. System/Bldg./Facility: } \\
\text { Tank Farms }\end{array}$ \\
$\begin{array}{c}\text { 12. Major Assm. Dwg. No.: } \\
\text { N/A }\end{array}$ \\
13. Permit/Permit Application No.: \\
N/A \\
\hline $\begin{array}{c}\text { 14. Required Response Date: } \\
\text { N/A }\end{array}$ \\
\hline
\end{tabular}
4. Related EDT No.:
7. Purchase Order No.: nent No.:

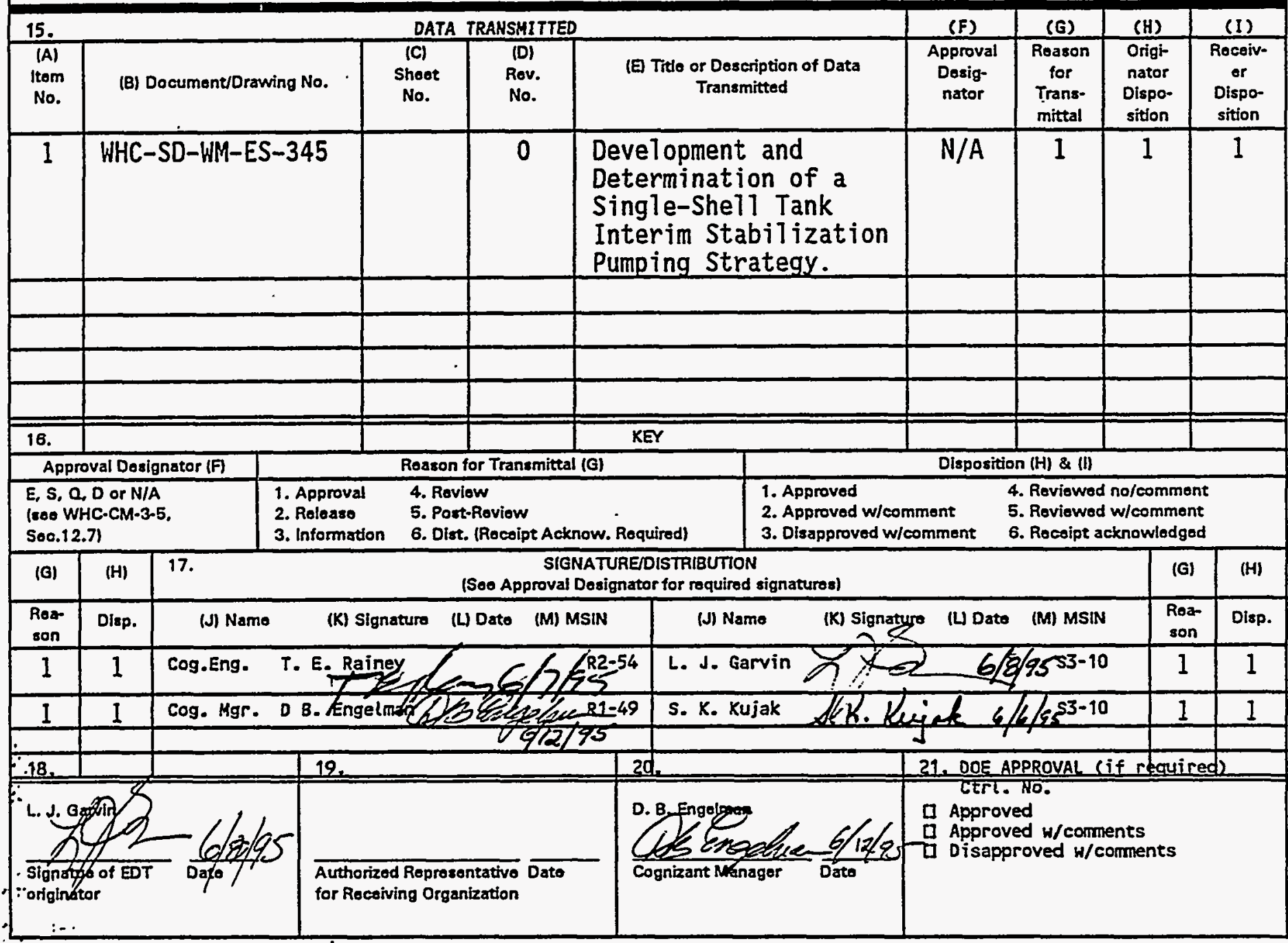




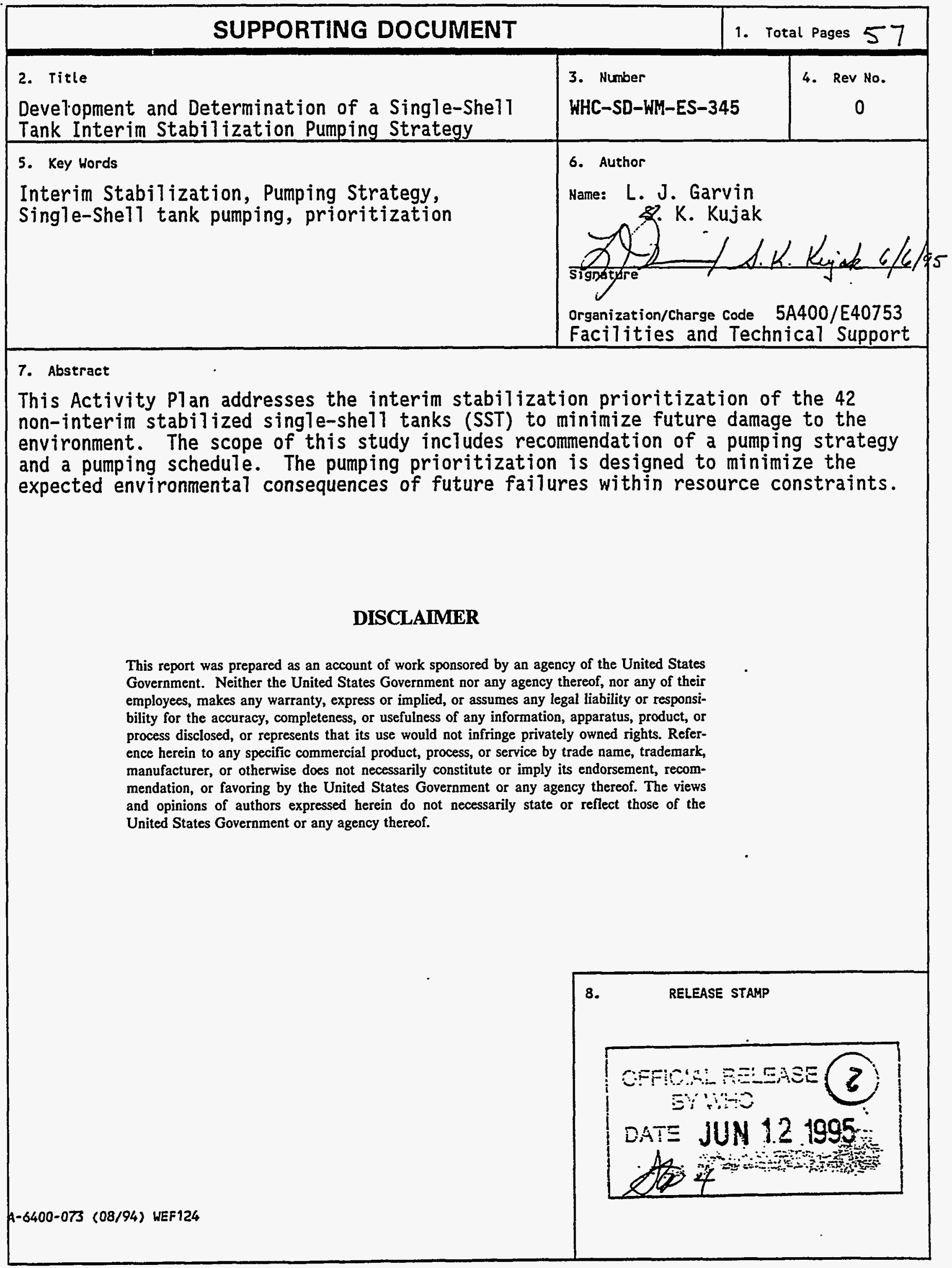




\section{RELEASE AUTHORIZATION}

Document Number: $\quad$ WHC-SD-WM-ES-345, REV 0

Document Title: Development and Determination of a Single-Shell Tank Interim Stabilization Pumping Strategy

Release Date: $\quad 6 / 12 / 95$

\section{This document was reviewed following the procedures described in WHC-CM-3-4 and is:}

\section{APPROVED FOR PUBLIC RELEASE}

WHC Information Release Administration Specialist:

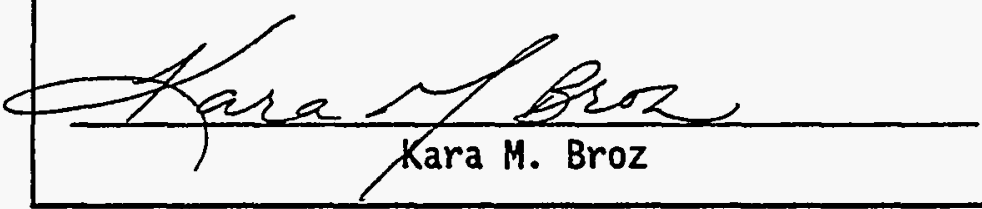

June 12, 1995

TRADEMARK DISCLAIKER. Reference herein to any specific commercial product, process, or service by trade name, trademark, manufacturer, or otherwise, does not necessarily constitute or imply its endorsenent, recommendation, or favoring by the United states Goverment or any agency thereof or its contractors or subcontractors.

This report has been reproduced from the best available copy. Available in paper copy and microfiche. Printed in the United States of America. Available to the U.S. Department of Energy and its contractors from:

U.S. Department of Energy

office of Scientific and Technical Information (OSTI)

P.0. $80 \times 62$

Oak Ridge, TH 37831

Telephone: (615) 576-8401

Available to the public from:

U.S. Department of Conmerce

Mational Technical Information Service (MTIS)

5285 Port Royal Road

Springfield, VA 22161

Telephone: (703) $487-4650$ 
ER4919ES, Rev. 2

ENGINEERING STUDY

FOR

\section{DEVELOPMENT AND DETERMINATION OF A SINGLE-SHELL TANK INTERIM STABILIZATION PUMPING STRATEGY}

\section{Prepared by}

ICF Kaiser Hanford Company

Richland, Washington

for

Westinghouse Hanford Company

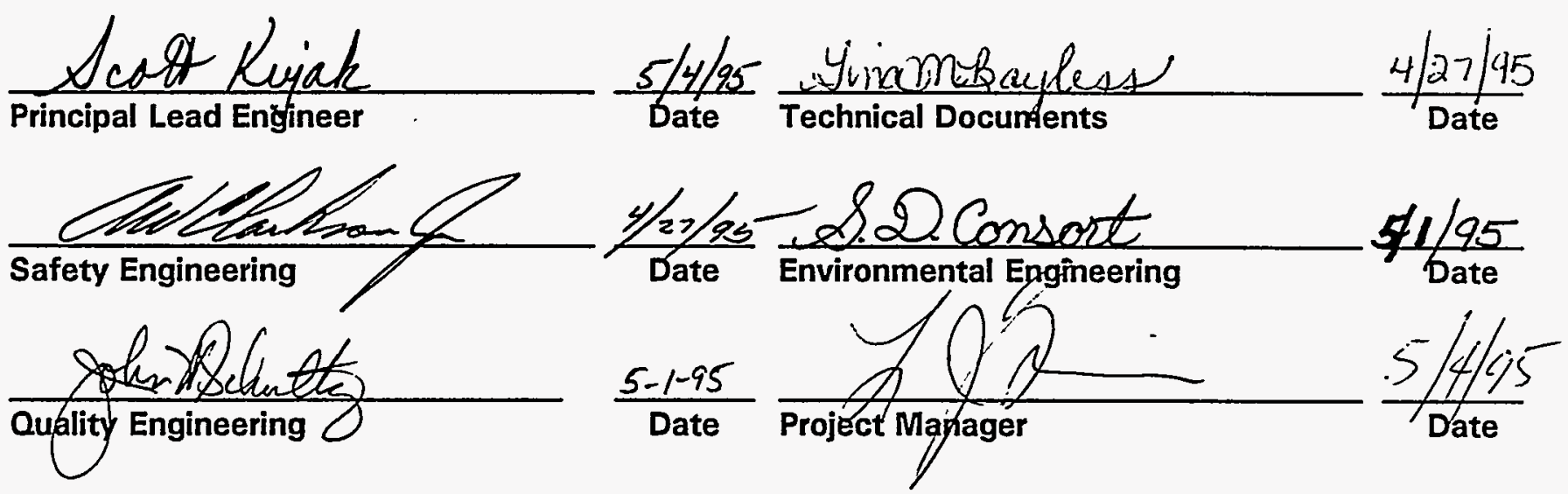

Westinghouse Hanford Company

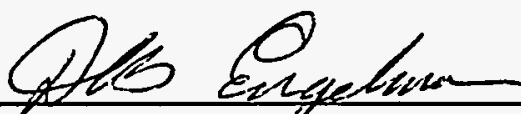




\section{TABLE OF CONTENTS}

1.0 OBJECTIVE ......................... 1

1.1 BACKGROUND AND SCOPE $\ldots \ldots \ldots \ldots \ldots \ldots \ldots \ldots$

1.2 PURPOSE AND NEED $\ldots \ldots \ldots \ldots \ldots \ldots \ldots \ldots \ldots \ldots$

2.0 SUMMARY $\ldots \ldots \ldots \ldots \ldots \ldots \ldots \ldots \ldots \ldots \ldots \ldots \ldots \ldots \ldots \ldots \ldots$

3.0 RECOMMENDATIONS AND CONCLUSIONS ............. 5

3.1 RECOMMENDATIONS ................... 5

3.2 CONCLUSIONS $\ldots \ldots \ldots \ldots \ldots \ldots \ldots \ldots \ldots \ldots \ldots \ldots \ldots$

4.0 UNCERTAINTIES $\ldots \ldots \ldots \ldots \ldots \ldots \ldots \ldots \ldots \ldots \ldots \ldots$

5.0 DESCRIPTION OF ALTERNATIVES AND APPROACHES ........ 8

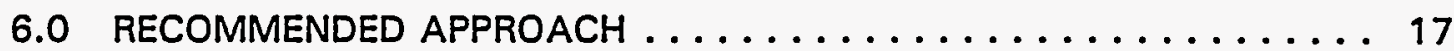

7.0 NO ACTION ALTERNATIVE ...................... 20

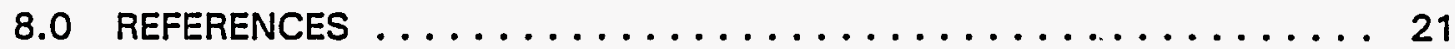
APPENDICES

Appendix A. Recommended Pumping Sequence and Comparisons Appendix B. Tables

Appendix C. Calculations and Backups for Recommended Pumping Sequence 


\section{ABBREVIATIONS}

\begin{tabular}{|c|c|}
\hline $\begin{array}{l}\text { DCRT } \\
\text { DOE } \\
\text { DSSF } \\
\text { DST }\end{array}$ & $\begin{array}{l}\text { double-contained receiving tank } \\
\text { U.S. Department of Energy } \\
\text { double-shell slurry feed } \\
\text { double-shell tank }\end{array}$ \\
\hline HVAC & heating, ventilating, and air-conditioning \\
\hline $\begin{array}{l}\text { SNM } \\
\text { SST }\end{array}$ & $\begin{array}{l}\text { special nuclear material } \\
\text { single-shell tank }\end{array}$ \\
\hline $\begin{array}{l}\text { TPA } \\
\text { TRAC }\end{array}$ & $\begin{array}{l}\text { Tri-Party Agreement } \\
\text { track radioactive components }\end{array}$ \\
\hline $\begin{array}{l}\text { WAC } \\
\text { WHC }\end{array}$ & $\begin{array}{l}\text { Washington Administrative Code } \\
\text { Westinghouse Hanford Company }\end{array}$ \\
\hline
\end{tabular}




\section{ENGINEERING STUDY \\ DEVELOPMENT AND DETERMINATION OF A SINGLE-SHELL TANK INTERIM STABILIZATION PUMPING STRATEGY \\ WORK ORDER ER4919}

\section{$1.0 \quad$ OBJECTIVE}

This study addresses interim stabilization prioritization of the remaining 42 noninterim stabilized single-shell tanks (SSTs) to minimize future damage to the environment. The scope of this study includes recommendation of a pumping strategy and pumping schedule. The pumping prioritization is designed to minimize the expected environmental consequences of future failures within resource constraints.

\subsection{BACKGROUND AND SCOPE}

The U.S. Department of Energy (DOE) owns several sites that manufacture, fabricate, or use special nuclear material (SNM). One DOE site is Hanford, located along the Columbia River in southeastern Washington State. The 560 square mile Hanford Site contains several SNM manufacturing and associated waste storage and treatment facilities. This report focuses on the waste storage tank facilities where liquid wastes from the plutonium/ uranium separation processes are stored.

The DOE has shifted its main objective from production of SNM to cleanup of facilities and restoration of its manufacturing sites. With approximately 50 years of SNM production at Hanford, large volumes of liquid waste byproducts that consist of radioactive and toxic chemical mixtures have accumulated. Liquid wastes are stored in large underground waste storage tanks that are clustered in rectangular arrays called tank farms. The tank farms are located in the 200-West and 200-East Areas of the Hanford Site. All tank farms are designated by the prefix 241 . Farms are identified by a single or double letter depending 
upon their location. Individual tanks are designated by numbers, frequently starting with 101, within a given tank farm (e.g., 241-SX Tank Farm and Tank 241-SX-101).

Between 1943 and 1964, 149 SSTs were designed and constructed in the 200 Areas. Wastes were added to these tanks from 1943 until November 1980 . Each of the 12 tank farms contains 4 to 18 SSTs. Twenty-eight double-shell tanks (DSTs) were fabricated and the first tank was put into service in 1971. The DSTs are arranged in six tank farms and each farm has between two and eight tanks. The DSTs were designed and constructed similar to the SSTs, but with an extra steel liner inside the tank, and were intended to store all the waste contained in the SSTs.

Most SSTs have exceeded their design life. Due to several factors, including the high number of failures (67 of 149 or $45 \%$ of the tanks are currently defined as "assumed" or "confirmed" leakers), the SSTs were taken out of service in November 1980. No new waste has been added to the tanks since that time. Tanks are called leakers if there is evidence of leaking that relates to a tank. Tanks are declared "confirmed leakers" if there is direct measurement evidence of leaking (i.e., a drop in liquid level). Tanks are declared "assumed leakers" only if there is indirect evidence of leaking (i.e., detected radioactivity in the surrounding soil) with no confirmation by measurement. The number of failures can be loosely associated with the age of the tanks.

Of the 149 SSTs, 106 have been interim stabilized which involves pumping as much liquid as possible to DSTs. Interim stabilization occurs when an SST contains less than $50,000 \mathrm{gal}$ of interstitial liquid (i.e., liquid trapped in the crystal structure) and less than $5,000 \mathrm{gal}$ of supernatant liquid. Pumping will usually continue until the flowrate decreases to $0.05 \mathrm{gal} / \mathrm{min}$. This interim stabilization step was taken to reduce the amount of leakage resulting from a tank failure.

Each of the 42 SSTs awaiting interim stabilization contains between 46,000 and $953,000 \mathrm{gal}$ of waste, much of which is pumpable liquid. Tank $241-B X-111$ is in the process of being interim stabilized. The 42 tanks contain about $5 \mathrm{Mgal}$ of pumpable liquid that must be moved into the DSTs. 
The SST failures and the increasing age of the tanks are indications that the remaining sound SSTs could start leaking. Therefore, the 42 tanks (i.e., 8 past leaking and 34 sound tanks) will be interim stabilized as the first step in the cleanup process and as an integral part of the ongoing DOE cleanup objective. Interim stabilization will minimize the environmental impact of tank leaking.

Tanks 241-C-106 and 241-C-105 are high-heat tanks and will not be interim stabilized in the same manner as the other SSTs, thus leaving 40 SSTs to be interim stabilized. The tanks generate large amounts of heat that boil away existing liquids and require additional water to control tank temperatures. Tank $241-\mathrm{C}-105$ is monitored by a process test and will be interim stabilized through evaporation. Tank 241-C-106 will be addressed during the retrieval program. High-heat tanks have exhibited the highest failure rate $(82 \%)$. Therefore, Tanks 241-C-105 and 241-C-106 appear to have a high potential for tank failure and the liquid waste should be transferred from them in the near future.

A statistical study of the failed SSTs was conducted to determine if correlations existed between the failures and tank content, tank usage, or tank fabrication characteristics that could be useful in prioritizing the pumping strategy. The correlation study and the consequential and random failure approaches were used as inputs and helped develop the recommended strategy, which results in a prioritized list of the remaining noninterim stabilized tanks and tank farms.

\subsection{PURPOSE AND NEED}

The noninterim stabilized tanks contain large volumes of radioactive and chemical wastes that are semi-liquid at best and very fluid at worst. Interim stabilization of the SSTs is a DOE objective and a critical step in the Hanford Federal Facility Agreement and Consent Order (Tri-Party Agreement [TPA]). Eventually, each SST will fail. The goal is to minimize the impact on the environment by sequentially stabilizing tanks according to the highest combination of risk and consequence. This study provides a technical basis for defining the stabilization priorities based on the age, fabrication characteristics, composition of contents, and volume of a tank along with the potential effects it may have on the environment. 
Four SST prioritization approaches were created and documented for this study: random failure, consequential, correlation, and recommended.

\section{Random Failure Approach}

The random failure approach assumed no correlation between tank failure and tank fabrication, use, or contents. Thus, each noninterim stabilized tank would have equal potential for failure. The resulting pumping order depends on the length of time required to pump the contents of the SST down to the interim stabilization criteria. Therefore, the tanks that can be pumped the fastest are pumped first. This approach quickly reduces the number of nonstabilized tanks and, therefore, the chance of a failure.

\section{Consequential Approach}

The consequential approach uses two mathematical models, a chemical model, and a radiological model to quantify the consequence of an environmental release based on a hazard rating of the tank contents. The models were applied to each tank and the resulting consequence numbers were summed to give a total consequence for the contents of each tank. The consequential score was divided by the tank volume and reported as a score per $1,000 \mathrm{gal}$ (Kgal). The scores were ranked by descending values to give the consequential pumping priorities.

\section{Correlation Approach}

The correlation study compared 30 tank characteristics with tank integrity (i.e., leaking or sound). The resulting indicators were ranked as having a significant correlation, mild correlation, or no correlation. Characteristics such as watch list designation, content type, and tank farm showed a significant or mild correlation with the tank status. 


\section{Recommended Approach}

The recommended approach was generated by combining the results of the other approaches to develop a list of SSTs by pumping priority. This approach used a mathematical computation to combine some features of the other approaches and focused on the risk associated with the contents of each tank and the propensity of a tank to fail/ leak. A value was calculated for each tank that combined the results from the consequence study (consequence value) and the correlation study (historical tank performance for similar tanks that have failed). The product of these values was used as an indicator of the risk associated with each tank.

The risk indicators were summed to give an indication of the total risk associated with SSTs that are not interim stabilized. Because of the time needed to prepare each tank farm for pumping and to resolve the various watch list tank safety questions, pumping priorities were chosen that would reduce the total risk associated with noninterim stabilized tanks.

The recommended prioritization listing based on a "normalized leak" (i.e., 5,000 gal) is shown in Table A-1 and as a curve of risk indicator versus time in Figure A-1 (see Appendix A). The DST availability, waste type compatibility, and transfer routings were investigated to provide guidance on the destination of the SST contents.

\section{RECOMMENDATIONS AND CONCLUSIONS}

\subsection{RECOMMENDATIONS}

The interim stabilization tank pumping sequence strategy and risk indicator versus time curves found in Table $A-1$ and Figure $A-1$ and the tank farm preparation and pumping schedule found in Figure A-6 should be followed (see Appendix A). The list was created by reviewing the three approaches and their results. From this review, a recommended prioritization pumping sequence that best satisfied the constraining factors was developed. The constraints can be defined as the time required to resolve the watch list issue, time to prepare the farms for pumping, pumping duration, possibility of transfer line failure and the renegotiated TPA schedule. Minimizing the risk of environmental impacts by pumping SSTs 
with characteristics common to leaking tanks and a large consequential risk due to the hazardous nature of the contents was considered.

Further studies should be conducted to gain insight into tank failure probabilities based on variable conditions that exist in the SSTs. Tank failure probabilities would assist in the decision making process if the pumping prioritization list from this study becomes outdated due to unanticipated changes.

Careful operational/engineering reviews should be conducted to determine the feasibility of pumping multiple tank farms at the same time and consolidating the remaining liquid waste into fewer SSTs.

\subsection{CONCLUSIONS}

Environmental risks vary between SSTs. Table B-4 contains the calculation of the risk indicators for the 40 SSTs associated with this study. There are at least two factors associated with risk: the consequence from the release of tank contents following failure, and the likelihood of failure of the noninterim stabilized SSTs. (See Section 6.0 for further information.)

Risk factors decrease as the SST waste is pumped and interim stabilization status is reached. However, some risk is associated with the interim stabilized status of SSTs. Two larger and four smaller interim stabilized SSTs have leaked.

Using the recommended pumping strategy reduces the unpumped tank risk more quickly than the preliminary strategy outlined in the TPA. Table A-1, Figure A-1, Table A-2, and Figure A-2 display the tables and curves related to the recommended pumping strategy and the TPA strategy, and the curves in Figure A-3 compare the recommended pumping strategy risk with the TPA pumping schedule risk (see Appendix A). Figure A-6 shows the recommended schedule for tank farm preparation and pumping.

Tank 241-BX-106 should be moved to the top of the pumping priority list because it has the highest risk indicator (i.e., the highest consequence per unit volume and a high 
likelihood of failure). The tank should be pumped as soon as the ferrocyanide issue is resolved and transfer lines can be installed; the existing transfer lines have failed.

Attention should be focused on manpower to expedite studies and resolution of the watch list tank concerns. As a result, tank farm preparation work would not need to be repeated when the watch list tanks in that farm are released for pumping. A more timely risk reduction can be attained by pumping entire tank farms without repeating labor efforts.

\subsection{UNCERTAINTIES}

Several uncertainties were found to exist during the çourse of this study. The uncertainties and the assumptions used in this study are listed below.

\section{Engineering Assessments}

1. The SST pumpable volumes indicated in the tank farm surveillance and the June 1993 waste status summary report were used (ref 3 ).

2. For the actual percent volume reduction of the 242-A Evaporator, $85 \%$ usually was used but $70 \%$ was assumed as a conservative estimate.

3. The DST and SST waste compatibility data in ref 3 and 7 were assumed. Additional sampling will be required to confirm compatibility.

4. The data in ref 7 were assumed for the DST waste type after volume reduction in the 242-A Evaporator.

5. An operable transfer system was assumed for failure time of the SST to DST liquid waste transfer system. Repair and replacement of systems known to have failed are included in the preparation time. 
6. Unavailable DST space resulting from administrative constraints, such as the segregated space in Tank 241-AW-103, was assumed to become available for interim stabilization use.

7. A preliminary date of spring 1994 was assumed for startup of the 242-A Evaporator. The evaporator started on schedule.

\section{Timing of Administrative Decisions}

1. The resolution date of unresolved safety questions for the ferrocyanide watch list tanks was March 1994. The resolution dates for organic and hydrogen watch list tanks will be June 1995 and March 1996, respectively.

2. The data found in the November 22, 1993 interim stabilization schedule were used to determine the timing and duration of the tank farm upgrades (i.e., mechanical; instrumentation; heating, ventilating, and air-conditioning [HVAC], etc.)

3. Review and approval time to commence pumping. The dates to begin pumping each tank farm were based on the assumption that review and approval had been completed.

\subsection{DESCRIPTION OF ALTERNATIVES AND APPROACHES}

\section{Random Failure Approach}

The goal of the random failure approach is to prioritize interim stabilization of the remaining 40 SSTs by maximizing the number of tanks stabilized per year (ref 9).

Due to the focus and timing of this approach to the study, no correlations between tank failures and tank characteristics or contents were assumed to exist. Assuming that the same failure likelihood applies to all tanks, the only factor that affects the yearly chance of 
tank failure is the number of tanks that have potential to fail because they are not interim stabilized. Although the exact likelihood of a tank failure in any given year was not determined, the risk can be decreased by reducing the number of tanks with failure potential. As a result, the overall yearly likelihood of tank failure becomes lower as each tank is stabilized.

The random failure approach primarily focuses on one factor that affects likelihood: the relative magnitude of time required to interim stabilize each SST including administrative review/approval, facility upgrades and preparation, and actual pumping time. The pumping time is dependent on the required tank farm upgrades, administrative review and approval, the content volume, the amount of saltcake with trapped interstitial liquid, and the amounts of supernatant liquid and semi-fluid sludge. The resulting ranking relies on the concept that by emptying the tanks that can be rapidly interim stabilized first, the number of tanks stabilized will accrue faster and, therefore, the overall yearly failure rate will be reduced more quickly. The ranking for this approach is listed in Table B-2 (see Appendix B). Because correlations between tank failures and tank characteristics were found after completion of this approach to the study, the rankings were not used directly in the final recommended pumping sequence.

The priorities identified by this approach account for or make assumptions for many factors (listed as Uncertainties in Section 4.0) that can impact the relative speed with which a particular tank can be interim stabilized. The factors include administrative approval time (especially for watch list tanks), preparation time to ensure that all needed lines are in the condition necessary to safely transfer the tank contents, and time for necessary tank farm upgrades to allow transfers to be conducted.

\section{Consequential Approach}

The consequential approach involves development of a prioritization scheme to interim stabilize the remaining 40 SSTs (ref 10 ). This approach focuses primarily on identifying the magnitude of hazards posed by the radiological and chemical contents of each tank. Radioactive and chemical composition data were obtained from track radioactive components (TRAC) which is a system of numerous computer models that work together 
to estimate the quantity of selected stable chemicals and radionuclides in each underground storage tank (ref 5).

Mathematical models were used to rank the total radioactive and chemical hazards associated with each SST being studied (ref 10 and 14). Separate models were used to assess the radiological and chemical damages caused by waste leakages from tanks independently. The radiological score and the chemical score of each tank were assigned a rank between 1 and 5 , based on the range that each score was in. The ranks were added and multiplied by 100 to obtain a total score for each tank. The total score of each SST was divided by its total pumpable volume of waste in kilogallons to reflect the concentration of radiological and chemical hazard. This score provides a basis for comparing the relative impact of a leak from each tank. The tanks were ranked in order of decreasing consequential scores to generate a sequence for interim stabilization of the remaining SSTs. The ranking for this study is shown in Table B-2 and the actual scores for each tank are listed in Table B-5 (see Appendix B). Sample calculations, based on the models for the chemical and radiological hazards associated with Tank 241-S-101, are shown in Appendix C.

\section{Correlation Approach}

The objective of the Pacific Northwest Laboratory correlation study was to identify relationships between the tanks that have leaked, the quantity of the liquid losses, and other characteristics of the 149 SSTs in the 200 Area on the Hanford Site (ref 11). The current tank data included in this study were age, the last year waste was added, the year the tank was declared an assumed leaker, design and construction specifications, and categories of contained waste.

The analyses provide a basis for developing a comprehensive strategy to complete the interim stabilization of SSTs that best minimizes the overall impact of actual and potential leaks. 


\section{Primary Findings}

The relationships between tank integrity status (i.e., assumed leaking or sound) and 16 other tank characteristics included in the study were investigated. Several characteristics were found to have statistically significant or mild relationships with tank integrity. The characteristics are summarized below. Currently, 67 SSTs $145 \%$ of the 149 SSTs) are classified as leaking and 82 SSTs (55\%) are classified as sound. This $45 / 55$ percentage split is used to interpret the results.

- Waste Group - The waste group characteristic (30 groups defined in ref 8 and 11) provided some significant insights. The $\mathbf{3 0}$ groups were defined by the four most prominent waste types from a list of 49 types. Group 1 had 22 tanks with REDOX high-level waste as the primary waste and evaporator bottoms as the secondary waste. Only $14 \%$ of the Group 1 SSTs leaked (perhaps because evaporator bottoms precipitate into a solid saltcake that could seal the liquid into the tank). Only five tanks in the group have been interim stabilized, but the low number of failures should lower the priority of the remaining 17 tanks to be interim stabilized.

- Watch List Classification - Classification of tanks by their watch list categories showed that the 15 flammable gas (hydrogen) watch list tanks had one leaking tank and 14 sound tanks. This $7 \%$ leaking/93\% sound split is removed from the expected $45 / 55$ percentage split on tank integrity; however, 9 of the 11 high-heat tanks $(82 \%)$ had leaked. Therefore, high-heat tanks should have a high pumping priority if leaking potential is the primary criterion for interim stabilization.

- Waste Type - Only 2 of the 11 double-shell slurry feed (DSSF) waste tanks $(18 \%)$ leaked. The other nine tanks are awaiting interim stabilization and should be placed low on the pumping priority list if leaking potential is the only consideration. 
The following characteristics showed some degree of correlation:

- Years Since Last Waste Added - Of the 20 tanks that last received waste between 1968 and $1972,80 \%$ were leaking which may relate to the waste type being added during that time period.

- $\quad$ Tank Farm - The percentage of leaking tanks in a farm ranged from $83 \%$ for the TY Tank Farm and $67 \%$ for the SX Tank Farm, to $25 \%$ for the U Tank Farm and $8 \%$ for the S Tank Farm. These statistics appear to be related to the type of waste being stored in the tanks and not related to the farm, the year the tank was built, or the contractor that built the tanks.

The findings from the correlation study are summarized in Table B-5 (see Appendix B). The statistic reported in the table as the contingency coefficient is a type of correlation coefficient that lies between 0 and 1.00. Characteristics tabulated against tank integrity are more likely to have occurred by chance. Therefore, a correlation between a characteristic and tank integrity is more likely as the value nears 1.00 if the coefficient value is large. For the purpose of this study, three broad categories of correlation coefficient with respect to tank integrity were used: "significantly related" (greater than 0.33 ), "may be related" (0.2 to 0.33 ), and "little or no relationship" (less than 0.2 ).

Time series data on liquid and solid waste levels of the SSTs from 1944 to 1993 and temperature profiles from the times when tanks had operational thermocouples were investigated but not analyzed in detail. The tank level data, available on a quarterly basis for most tanks, were difficult to interpret and were not available for most of the tanks that were taken out of service in 1980. The data were supposed to be used to develop indicators of tank stress due to loading and unloading volume fluctuations and temperature fluctuations. Data, time, and funding limitations did not allow full investigation of the potential to use the data as indicators of leak propensity. Therefore, the other tank characteristic data were more valuable than the time series data.

The findings relating to the random failure study, the consequential study, and the correlation study are shown in Table B-1 (see Appendix B). 
Space Availability

As part of the interim stabilization process, $5,048 \mathrm{Kgal}$ of SST waste must be transferred to existing DSTs. There are 28 DSTs that may be available for interim stabilization of the SSTs. Some of the tank space is unavailable due to administrative or other constraints; therefore, the affected tanks are considered unavailable for this study. Some of the DST space has been allocated for other projects, but is assumed to be available (if needed) to support the interim stabilization process. This assumption may not be valid because of other site priorities. However, studies indicate that sufficient DST space should be available without the assumptions. Within the 28 DSTs, $2,775 \mathrm{Kgal}$ of space are available to receive SST waste: $411 \mathrm{Kgal}$ are available in the 200-West Area and 2,364 Kgal are available in the 200-East Area.

The 242-A Evaporator is expected to restart in the spring of 1994. The first evaporator campaign is scheduled to be completed at the start of 1995 . Projections indicate that the DST waste involved will be reduced by $70 \%$, creating $2,015 \mathrm{Kgal}$ of additional space (ref 6 and 7). The newly created space from the evaporator is assumed to be available for SST interim stabilization efforts. The second campaign is scheduled to be completed by the start of 1996 , creating an additional $2,154 \mathrm{Kgal}$ of space for SST interim stabilization (ref 7).

New DSTs are being proposed for the 200-East and the 200-West Areas. Two new DSTs are planned for construction in the 200-West Area and may be available as early as 1996 to 1998. Four new-DSTs in the 200-East Area are scheduled to be completed before the year 2000. Each new DST will have a 1.16-Mgal capacity (ref 11 ).

Chart 1 illustrates current and projected available space within DST farms to receive SST waste as part of the interim stabilization process. Though compatibility between SST waste and DST waste may affect SST interim stabilization efforts, the chart demonstrates that sufficient space will be available to support the efforts throughout the course of the project. The total volume of SST pumpable waste to be transferred is approximately $5,048 \mathrm{Kgal}$ and more than $13,000 \mathrm{Kgal}$ of space will be made available by the end of 1997 
as shown on the chart (ref 3). The proposed new DSTs will add an additional $2 \mathrm{Mgal}$ of space by 1998 .

\begin{tabular}{||l|l|c||}
\hline \multicolumn{2}{|c|}{ Condition/Event } & \multicolumn{1}{c|}{ Available DST Space } \\
\cline { 2 - 4 } & \multicolumn{1}{|c|}{ By Project } & \multicolumn{1}{c||}{ Accumulated } \\
\hline Current Available Space & $\begin{array}{l}2,775 \mathrm{Kgal} \\
\text { West: } 441 \mathrm{Kgal} \\
\text { East: } 2,364 \mathrm{Kgal}\end{array}$ & \\
\hline $\begin{array}{l}\text { 1995: First evaporator campaign } \\
\text { completed }\end{array}$ & $2,015 \mathrm{Kgal}$ & $4,790 \mathrm{Kgal}$ \\
\hline $\begin{array}{l}\text { 1996: Second evaporator campaign } \\
\text { completed }\end{array}$ & $2,154 \mathrm{Kgal}$ & $6,944 \mathrm{Kgal}$ \\
\hline $\begin{array}{l}\text { 1996-1997: Evaporator continues to } \\
\text { reduce waste volumes, making } \\
\text { 255 Kgal/month available (ref 2) }\end{array}$ & $6,120 \mathrm{Kgal}$ & $13,064 \mathrm{Kgal}$ \\
\hline $\begin{array}{l}\text { 1998: Completion of two additional } \\
\text { DSTs in 200-West Area }\end{array}$ & $2,320 \mathrm{Kgal}$ & $15,384 \mathrm{Kgal}$ \\
\hline \hline
\end{tabular}

\section{SST to DST Compatibility}

Besides DST space availability, the compatibility of SST and DST waste types is another criterion for SST pumping. When an SST is ready to be pumped, a process grab or dip sample is obtained from the SST and the designated receiver DST. The samples are analyzed to confirm waste type and thus compatibility according to the Westinghouse Hanford Company (WHC) tank waste capability program (ref 12). For samples that are incompatible with the designated receiver DST, a different receiver DST is established. If the corrosion specification criteria is violated, the SST liquid effluent can be chemically adjusted to DST specifications when the waste reaches the double-contained receiving tank (DCRT) (this method was used during the pumping of Tank 241-T-101) or a new DST can be designated (ref 13). The investigations and Chart 1 indicate that tank space is or will be available in the 200 Area for all SST contents. The 200-West Area space is limited and failure of the cross-site transfer lines will make completion of any schedule difficult. There are more than $3,500 \mathrm{Kgal}$ of pumpable SST liquid for the $411 \mathrm{Kgal}$ of available DST space 
in the 200-West Area. Table B-3 summarizes the DST and SST compatibilities and DST volume availabilities (see Appendix B).

\section{Sensitivity Analysis}

Various assumptions were made to develop the recommended pumping approach. An evaluation was conducted to determine which assumptions were the most sensitive and, therefore, the most constraining to the recommended pumping approach. Sensitivity is delaying or halting the interim stabilization process. Assumptions that fall within the sensitivity category are the waste transfer system, DST space availability, and SST to DST waste compatibility.

The pumping strategy is very sensitive to the condition of the cross-site transfer system. The most critical concern is the transfer system between the 200-East and 200-West Areas. The current transfer system has six lines, four of which are plugged or have failed the hydrostatic test. This condition will abate when the new east-west transfer line from project $W-058$ is completed on or about January 1998. If the present east-west transfer line fails, routing through the terminus would have to be halted. The greatest effect would be on the 200-West Area because it contains only three DSTs (i.e., one available DST and two watch list DSTs) with limited space availability and the largest SST volumes to be transferred. The only alternatives to this condition would be to use aboveground transfer lines, truck, or rail tank car transfer methods to accomplish east-west movement around the failed pipe sections, or the entire east-west transfer line; accelerate the DST completion schedule; or accelerate the east-west transfer line completion schedule.

The recommended SST pumping prioritization is very sensitive to DST space availability and somewhat sensitive to DST waste compatibility. If the 242-A Evaporator does not start up in 1994 or 1995 and continue to run, then the necessary space will not be created which could force a complete halt in the ongoing SST interim stabilization. If for some reason the evaporator startup is rescheduled to 1996 or later or the evaporator is not reliable, management should consider combining the contents of compatible SSTs to lower the number of tanks subject to failure, thereby lowering the chance of tank failures occurring per year (i.e., the random failure approach). Accelerating the DST construction project for 
earlier tank completion and usage should be considered also. Failure to construct the DSTs now planned would greatly impact the ability to interim stabilize the remaining noninterim stabilized SSTs.

The liquid waste compatibility concerns can be resolved in various manners. The SST liquid waste may be chemically adjusted as it is accumulated in a DCRT awaiting further transfer to a designated DST. If the adjustment is not possible, the 242-A Evaporator can be scheduled to create DST space for that specific waste type. If the 242-A Evaporator is not online, consolidation of equivalent DST waste types into fewer DSTs can create DST space for the SST waste type under consideration. Although the consolidation does not create space, the new arrangement of existing space may provide some operational flexibility and benefits.

There is not enough DST space for complexed waste now stored in the SSTs. Using the recommended pumping sequence, the available DST space for complex waste would be used by mid-1996 following the pumping of Tanks 241-C-102, 241-C-107, 241-C-110, and 241-U-107. One of the following actions must be taken before available DST space runs out:

- Redesignate a noncomplexed DST as a complexed tank.

- Include a complexed waste DST when scheduling further evaporator campaigns.

- Reschedule the current defined evaporator campaigns to include a complexed DST.

All available DST complexed space is located in the 200-East Area which is another indication of the impact of an east-west transfer system failure. 


\subsection{RECOMMENDED APPROACH}

Data and results compiled from the consequential and correlation approaches were used to develop the recommended approach. The consequence of a tank failure was combined with the likelihood of tank failure to indicate the environmental risk of each tank.

In order to develop an indicator of the risk related to each noninterim stabilized SST, the calculated consequence rating for each tank was selected from the consequence approach and the historical tank failure performance for similar tanks/contents was selected from the correlation portion of this study. For failed tanks that exhibited correlations with more than one tank characterization, the higher likelihood of failure was used to provide a more conservative indication. For tanks that had no characteristics exhibiting correlations with the failed tanks, the average tank failure history (i.e., $45 \%$ ) was used to indicate an average likelihood of failure. For each tank, the consequence rating was multiplied by the likelihood of tank failure to indicate the risk associated with the tank. The risk indicator was calculated using the entire contents of the tank and separately on a normalized leak (i.e., 5,000 gal) basis to compare results.

The normalized leak basis was investigated because of indications that tank leakage over the last 10 to 15 years has ranged between 2,000 and 5,000 gal rather than the entire tank capacity. A loss of $5,000 \mathrm{gal}$ was chosen as the normalized most likely detectable leak. The risk indicator calculations are on Table B-4 for the entire tank contents and Table B-4a for the normalized leak (see Appendix B). For the purpose of this study, a normalized leak was used to develop the pumping strategy. However, the final recommended pumping sequence was checked using the entire tank content risk indicators to see if there may be a different pumping sequence. The recommended pumping priorities are the same under both assumptions.

The risk associated with the failure of interim stabilized tanks was investigated for this study. There are 94 SSTs sized from $530,000 \mathrm{gal}$ to $1.1 \mathrm{Mgal}$ and sixteen $55,000 \mathrm{gal}$ tanks that have been interim stabilized. Two larger tanks and four smaller tanks have leaked since interim stabilization. The volume that leaked from the two larger tanks averaged approximately 6,000 gal. Previous criteria for interim stabilization allowed more 
liquids to be present in the early tanks that were pumped; therefore, more content could leak after failure. The risk associated with interim stabilized tanks, while lower than noninterim stabilized tanks, does not appear to have decreased to zero.

To calculate the risk indicators associated with interim stabilization status of the 40 tanks involved with this study, a $5 \%$ likelihood of tank failure (i.e., 6 out of 110 tanks have leaked) with $3,000 \mathrm{gal}$ of leakage was assumed. These values were chosen to give a degree of conservatism and the decrease in risk that could be accomplished by interim stabilization. The calculations are shown in Tables B-4 and B-4a (see Appendix B).

Summing the risk indicators associated with a normalized leak from each noninterim stabilized tank gives an indication of the total risk related to the 40 SSTs. Plots outlining total risk versus time of several pumping strategies were used for a strategy comparison. Total risk decreases as SSTs are pumped. The pumping sequence that most quickly reduced risk and stayed within real or assumed constraints was recommended. The strategy is given in Figure A-1 and Table A-1 (see Appendix A). The time to prepare a tank farm for pumping (including testing time) and the time to pump the liquid from tanks within the farm were considered in the development of the recommended pumping sequence. The times plotted against the total content risk of the tank farm are shown in Figure A-5 (see Appendix A). The schedule for tank farm preparation and pumping is shown in Figure A-6 (Appendix A). Preparing and pumping a few tanks and then moving to another farm or farms before returning requires that labor and testing be redone to prepare for the next pumping cycle. The recommended pumping strategy is arranged on an entire tank farm basis, except for Tanks 241-C-103, 241-T-111, the 241-BY Farm tanks, and the watch list tanks in the $S$ Tank Farm to reduce wasted labor. The following assumptions were considered to prepare the WHC Tank Waste Remediation Systems interim stabilization schedule:

- Work force limitations: Three tank farms can be prepared for pumping at the same time except that Tank 241-T-111 was prepared on an emergency basis along with three other tank farms.

- Dates for watch list concern resolution. 
- Dates for completion of the aboveground transfer line for Tank 241-BX-106 waste transfer.

- Tank pumping constraint: Two tanks per farm are pumped at full flow, or several are pumped at the lower flowrates as interstitial liquid is removed.

The logic used to produce the recommended pumping sequence. (See the schedule in Figure A-6 and Table A-1 and Figure A-1 in Appendix $A$ for the risk indicator versus time calculations and curves).

Currently, the BY, $\mathrm{C}$, and S Tank Farms are being prepared for pumping and Tank $241-B X-111$ is being pumped. Tank $241-B X-106$ was preferred to be pumped first but it is a watch list tank with only $15 \mathrm{Kgal}$ of pumpable liquid and has nonfunctional transfer lines. (Over the surface transfer lines will be needed.) Taking the preparation momentum into account, parts of the BY Tank Farm and most of the C Tank Farm were chosen to be pumped first. The time needed to prepare the nonwatch list tanks in the $S$ Tank Farm delays the start of pumping in this farm until early 1996. The preparation times used for these two farms include the time needed to prepare the extra (more than in the current TPA schedule) tanks. The need to move quickly in order to gain waivers for pumping Tank 241-C-103 (a watch list tank) should be considered to avoid wasted labor (shown in this strategy) by preparing the farm again for later pumping.

Tank 241-BX-106 was chosen to be next in the sequence because of the time needed to prepare over the surface transfer lines. The T Tank Farm was chosen to be pumped with the recommendation that waivers be obtained to pump Tank 241-T-110 (a hydrogen watch list tank) without the wasted labor (shown in this pumping strategy) to prepare the $T$ Tank Farm for repumping a few months later when full approval to pump watch list tanks is anticipated. Then the nonwatch list tanks in the $S$ Tank Farm can start pumping. The $U$, SX, S (watch list tanks), AX, and A Tank Farms will be pumped respectively.

The constraints on the transfer of Tank 241-BX-106 should be addressed as soon as possible because the contents should be pumped quickly. Tank 241-BX-106 has the largest risk indicator which means that the consequence and likelihood of failure are high. Further 
studies and the resolution of the associated concerns related to the watch list tanks should be expedited to optimize the labor used to prepare a tank farm for pumping.

Table A-2 and Figure A-2 show the TPA pumping sequence and its related curve of risk indicator for a normal leak versus time comparison. Figure A-3 shows the plots of the TPA and the recommended pumping strategies on a normalized leak basis on the same graph to indicate the degree of risk associated with each pumping sequence.

Figure A-4 shows the effect of pumping Tank $241-\mathrm{BX}-106$ earlier than the present TPA scheduled time. These figures show the drop in risk indicator only when a milestone or tank farm pumping has been completed; therefore, the actual reduction of risk indicator may be quicker than what is shown on Figure A-4. The figure supports the recommendation to pump Tank 241-BX-106 quickly.

Table $\mathrm{C}-3$ and Figure $\mathrm{C}-3$ relate to the recommended pumping strategy but are based on the assumption that the entire contents of each tank leak, Table C-4 and Figure C-4 indicate the TPA schedule based on the same assumption, and Figure C-5 is a comparison of the recommended pumping strategy and the TPA pumping sequence based on the entire contents of each tank (see Appendix $\mathrm{C}$ ). There is no difference in the pumping order used in either the normalized leak approach or the entire tank content approach.

\subsection{NO ACTION ALTERNATIVE}

The section for this alternative is included in the study for format purposes. No action is not believed to be a viable option for the SST contents. The TPA includes specific milestones for stabilization of the SSTs.

The consequences of doing nothing can be costly and far reaching. Leaving the noninterim stabilized SST tanks as is will increase the amount of leaking SSTs and the chance for a large long-term environmental impact. The impact would cause a significant increase in costs, cleanup efforts, and a large impact on public relations that could turn into a political issue. As the SSTs and the transfer system age, they will exceed their design life if they 
haven't already which will make later transfers more hazardous with increased likelihood of leaks. Interim stabilization of the remaining SSTs is more beneficial to limit costs, cleanup effort, and further damage to the environment as much as possible.

\subsection{REFERENCES}

1. Washington State Department of Ecology, "Dangerous Wastes Regulations, Tank Systems, Chapter 173-303-640-WAC," 1992.

2. Report, "Managing The Assumed Leak From Single-Shell Tank 241-T-101," Document No. ER3415ER, Rev. 1, prepared by Kaiser Engineers Hanford Company, March 1993.

3. Report, "Tank Farm Surveillance and Waste Status Summary Report for June 1993," prepared by Westinghouse Hanford Company, Document No. WHC-EP-0182-63, October 1993.

4. Internal Memorandum, Kaiser Engineers Hanford Company, "Requested Information for the Determination of a Probabilistic or Consequential SST Pumping Approach," prepared by S.K. Kujak, September 7, 1993.

5. Report, "Preliminary Estimation of the Waste Inventories in Hanford Tanks through 1980," prepared by Rockwell Hanford Operations, Document No. RHO-SD-WM-TI-057, March 1984.

6. Internal Memorandum, Kaiser Engineers Hanford Company, "Questions Raised at ER4010 Meeting," prepared by S.K. Kujak, September 21, 1993.

7. Internal Memorandum, Kaiser Engineers Hanford Company, "Present and Future Available Double-Shell Tank Space for the Pumping of Single-Shell Liquid Waste (ER4919) and a Tank-by-Tank Compatibility Comparison," prepared by S.K. Kujak, October 7, 1993. 
8. Report, "The Sort on Radioactive Waste Type Model: A Method to Sort Single-Shell Tanks into Characteristic Groups," prepared by Westinghouse Hanford Company, Document No. WHC-EP-0449, August 1991 (draft).

9. Letter Report, "Probabilistic Prioritization for the Interim Stabilization of the Single-Shell Tanks, " prepared by Kaiser Engineers Hanford Company, Document No. ER4919LR, December 1993.

10. Letter Report, "Consequential Prioritization for the Interim Stabilization of the Single-Shell Tanks," prepared by Kaiser Engineers Hanford Company, Document No. ER4919LR2, December 1993.

11. Letter Report, "Prioritization of Interim Stabilization of SSTs (Correlation Study)," prepared by Pacific Northwest Laboratory, November 1993.

12. Report, "Tank Farm Waste Compatibility Program," prepared by Westinghouse Hanford Company, Document No. WHC-SD-WM-OCD-0115, November 1, 1991.

13. Letter, C.H. Brevick (Kaiser Engineers Hanford Company) to R.R. Stickney (Westinghouse Hanford Company), "Single-Shell Tank Noninterim Stabilized Liquid Sample Data Table - ER3784-03," August 9, 1993.

14. Report, "Preliminary Estimation of the Waste Inventories in Hanford Tanks through 1980," prepared by Rockwell Hanford Operations, Document No. RHO-SD-WM-TI-057, March 1984. 





TABLE A-1

RECOMMENDED PUMPING SEQUENCE USING A 'NORMALIZED' LEAK

\begin{tabular}{|c|c|c|c|c|c|}
\hline FARM & $\begin{array}{l}\text { SST (IN ORDER } \\
\text { OF PUMPING } \\
\text { PRIORITY) }\end{array}$ & $\begin{array}{c}\text { RISK DECREASE PER } \\
\text { FARM }\end{array}$ & $\begin{array}{c}\text { ESTIMATED INTERIM } \\
\text { STABILIZATION TIME } \\
\text { (DAYS) }\end{array}$ & $\begin{array}{l}\text { INTERIM } \\
\text { STABILIZATION } \\
\text { START DATE }\end{array}$ & $\begin{array}{c}\text { INTERIM } \\
\text { STABILIZATION } \\
\text { COMPLETION } \\
\text { DATE }\end{array}$ \\
\hline & & $\begin{array}{c}776.38 \text { (TOTAL from } \\
\text { TABLE B-6a) }\end{array}$ & & $10 / 1 / 93$ & \\
\hline$T$ & $T-111$ & 9.32 & 317 & $5 / 17 / 94$ & $3 / 30 / 95$ \\
\hline BY & $\begin{array}{l}\text { BY-109, } \\
\text { BY-102 }\end{array}$ & 92.59 & 215 & $5 / 30 / 94$ & $12 / 31 / 94$ \\
\hline C & $\begin{array}{c}\mathrm{C}-107, \mathrm{C}-102 \\
\mathrm{c}-110\end{array}$ & 233.77 & 92 & . $9 / 30 / 94$ & $12 / 31 / 94$ \\
\hline BY & $\begin{array}{l}\text { BY-106, } \\
\text { BY-105, } \\
B Y-103\end{array}$ & 40.60 & 546 & $6 / 1 / 95$ & $11 / 28 / 96$ \\
\hline $\mathrm{BX}$ & $B X-106$ & 193.34 & 15 & $6 / 1 / 95$ & $6 / 16 / 95$ \\
\hline $\begin{array}{l}5 \text { ( non-WATCH } \\
\text { LIST TANKS) }\end{array}$ & $\begin{array}{c}\text { S-107, S-103, } \\
\text { S-109, S-101, } \\
\text { S-108, S-110, } \\
\text { S-108 }\end{array}$ & 30.61 & 414 & $1 / 2 / 98$ & $2 / 19 / 97$ \\
\hline$T$ & $\begin{array}{c}T=104, T-110 \\
T-107\end{array}$ & 56.45 & 143 & $5 / 22 / 96$ & $10 / 12 / 96$ \\
\hline c & $C-103$ & 6.62 & 133 & $6 / 30 / 96$ & $11 / 10 / 96$ \\
\hline$u$ & $\begin{array}{l}\text { U-102, U-111, } \\
\text { U-106, U-107, } \\
\text { U-108, U-109, } \\
U-103, U-105\end{array}$ & 24.23 & 406 & $7 / 26 / 96$ & $9 / 5 / 97$ \\
\hline $\begin{array}{c}\text { S ( WATCH LIST } \\
\text { TANKS) }\end{array}$ & $\begin{array}{c}\text { S-102, s-112, } \\
\text { S-111 }\end{array}$ & 10.02 & 531 & $10 / 24 / 96$ & $4 / 8 / 98$ \\
\hline A & A-101 & 1.34 & 996 & $12 / 27 / 96$ & $9 / 19 / 99$ \\
\hline$A X$ & $A X-101$ & 1.76 & 761 & $4 / 22 / 97$ & $5 / 23 / 99$ \\
\hline sx & $\begin{array}{l}\mathrm{s} \times 106, \mathrm{~s} \times 102, \\
\mathrm{~s} \times 101, \mathrm{~s} \times 103, \\
\mathrm{~s} \times 104, \mathrm{~s} \times 105\end{array}$ & 16.43 & 609 & $8 / 8 / 97$ & $4 / 9 / 99$ \\
\hline
\end{tabular}

To create the Recommended Approach Schedule certain essumptions were made:

i) SSTs 241-BY-102 \& 241-BY-109 preparation for pumping will be completed by 5/30/94

ii) only 3 farms are to be prepared for pumping at the same time (with the exception of 241-T-111). 


\section{RISK EVALLUATION}

RECOMMENDED PUMPING APPROACH SEQUENCE USING A 'NORMALIZED' LEAK

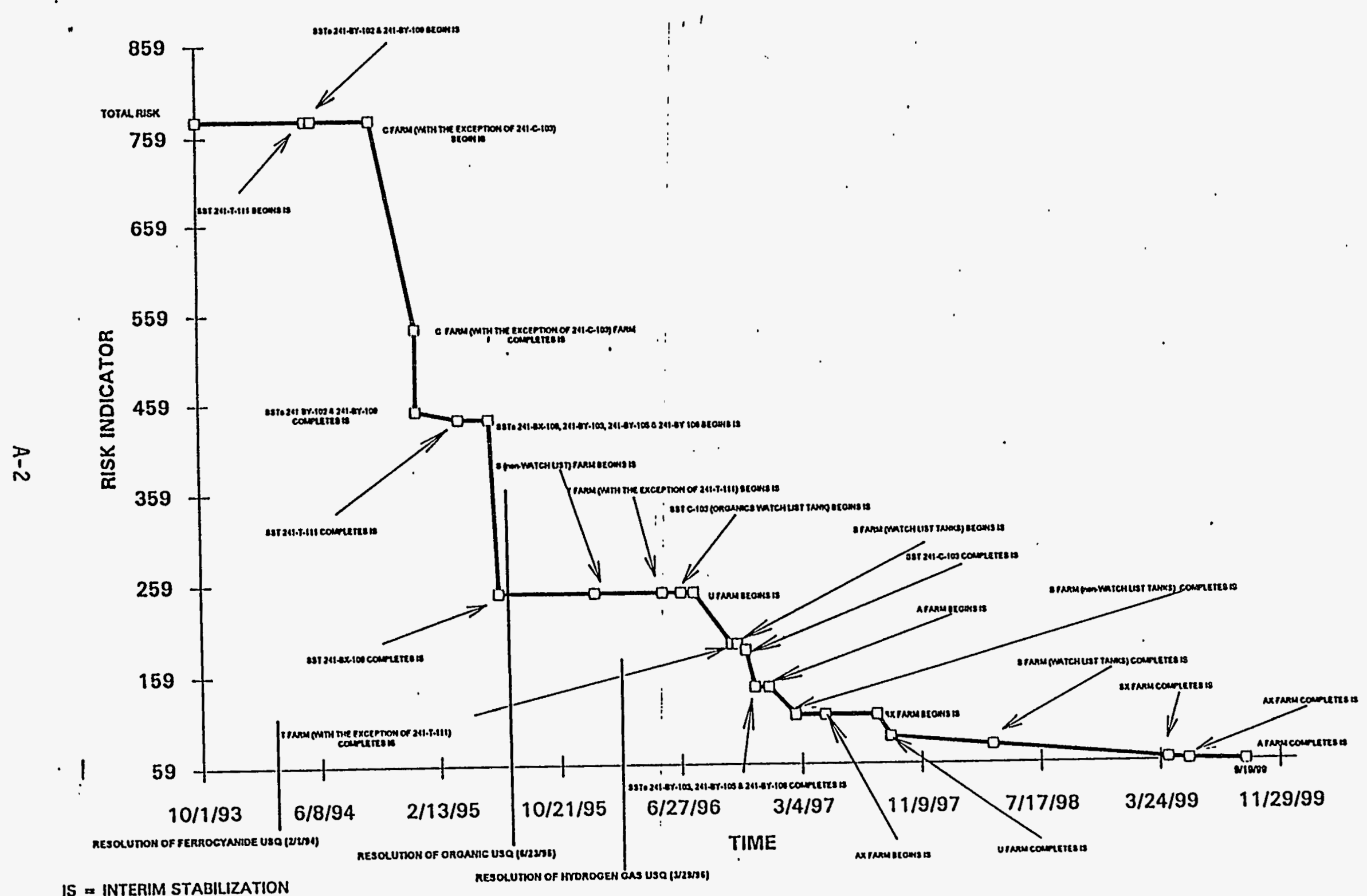


TABLE A-2

\section{TPA MILESTONE PUMPING SEQUENCE USING A 'NORMALIZED' LEAK}

\begin{tabular}{|c|c|c|c|c|c|}
\hline TPA MILESTONE & SST & $\begin{array}{l}\text { RISK DECREASE PER } \\
\text { MILESTONE }\end{array}$ & $\begin{array}{c}\text { INTERIM STABILIZATION } \\
\text { TIME (DAYS) }\end{array}$ & $\begin{array}{c}\text { INTERIM } \\
\text { STABILIZATION START } \\
\text { DATE }\end{array}$ & $\begin{array}{c}\text { INTERIM } \\
\text { STABILIZATION } \\
\text { COMPLETION DATE }\end{array}$ \\
\hline & & $\begin{array}{c}776.38 \text { (TOTAL from } \\
\text { TABLE B-6a) }\end{array}$ & & $10 / 1 / 93$ & \\
\hline$M-49-01-T 3$ & BY102, BY109 & 92.59 & 215 & $5 / 30 / 94$ & $12 / 31 / 94$ \\
\hline$M-41-09-T 1$ & $\begin{array}{l}\text { C102, C107. } \\
\text { C110 }\end{array}$ & 233.77 & 92 & $9 / 30 / 94$ & $12 / 31 / 94$ \\
\hline$M-41-08$ & U102. & 8.61 & 285 & $7 / 12 / 95$ & $4 / 22 / 96$ \\
\hline$M-49 \cdot 13$ & $\begin{array}{l}\text { U105. U107. } \\
\text { U111 }\end{array}$ & 13.81 & 509 & $7 / 12 / 95$ & $12 / 2 / 96$ \\
\hline$M-41.09$ & $\begin{array}{l}\text { S101, } 5103, \\
5106,5107, \\
5108,5109, \\
\text { s110 }\end{array}$ & 30.61 & 456 & $\begin{array}{c}1 / 3 / 96 \\
.\end{array}$ & $4 / 3 / 97$ \\
\hline$M-41-11$ & $\begin{array}{l}\text { U103, U105, } \\
\text {.. U108, U109 }\end{array}$ & 1.89 & 407 & $4 / 1 / 96$ & $5 / 13 / 97$ \\
\hline$M-41-10$ & $\because A 101, A \times 101$ & 3.11 & 984 & $4 / 18 / 96$ & $12 / 28 / 98$ \\
\hline$M-49-12$ & $\begin{array}{l}\text { BX106; BY103, } \\
\text { BY105, BY106 }\end{array}$ & $\cdots 233.94 \quad \because=$ & $\cdots \cdots 545$ & $-4 / 1 / 97$ & _9/28/98 \\
\hline$M-41-14$ & $\begin{array}{c}5111,5112, \\
5 \times 101,5 \times 102, \\
5 \times 103,5 \times 104, \\
5 \times 105 \\
\end{array}$ & 20.50 & 871 & $6 / 20 / 97$ & $19 / 8 / 99$ \\
\hline$M-49.15$ & $5102,5 \times 106$ & 5.94 & 627 & $6 / 20 / 97$ & $3 / 9 / 99$ \\
\hline$M-49-16$ & T104. T111 & $28.41-$ & 153 & $3 / 24 / 98$ & $8 / 24 / 98$ \\
\hline$M-41-17$ & $T 107$ & 36.25 & 34 & $4 / 1 / 98$ & $5 / 5 / 98$ \\
\hline$M-41-18$ & $T 810$ & 1.11 & 197 & 4/1/98 & $7 / 27 / 98$ \\
\hline$M-41-19$ & C103 & 6.62 & 164 & $9 / 18 / 98$ & $3 / 1 / 99$ \\
\hline
\end{tabular}


WHC-SD-WM-ES-345, Rev 0

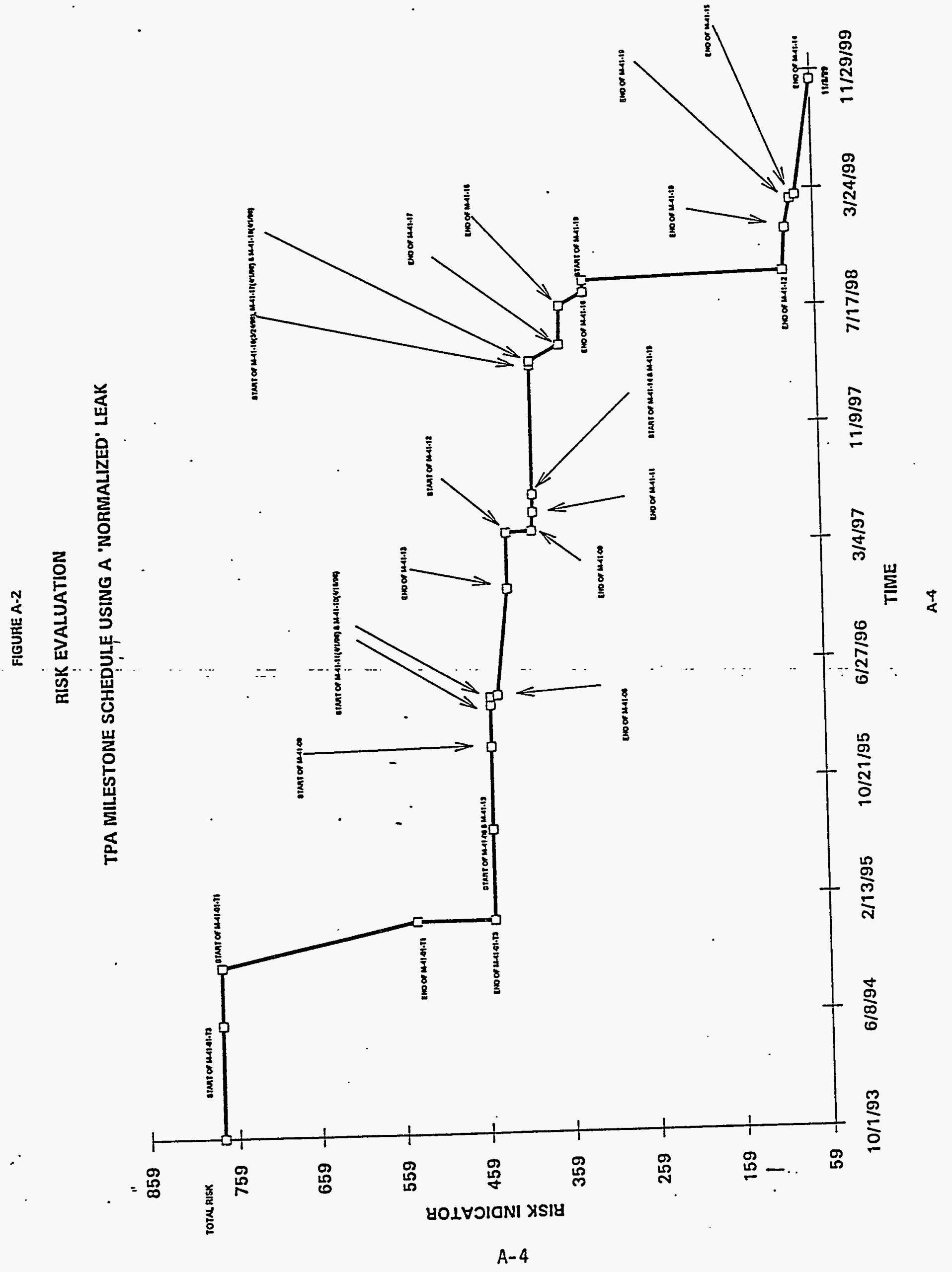




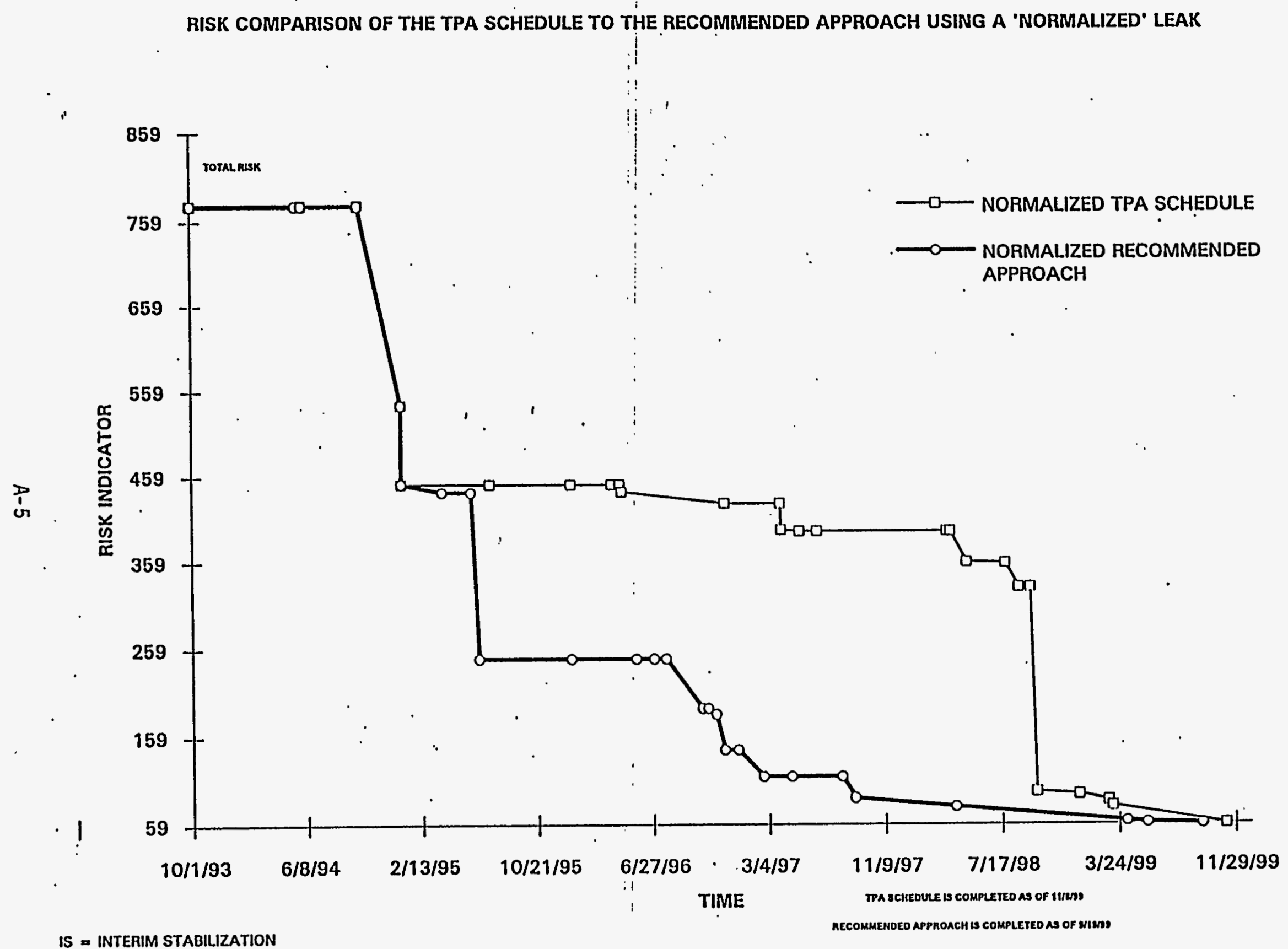

Figure A-3 
RISK COMPARISON OF THE TPA SCHEDULE, TPA SCHEDULE WITH BX-106 SHIFTED TO MILESTONE M-41-08 AND THE RECOMMENDED APPROACH

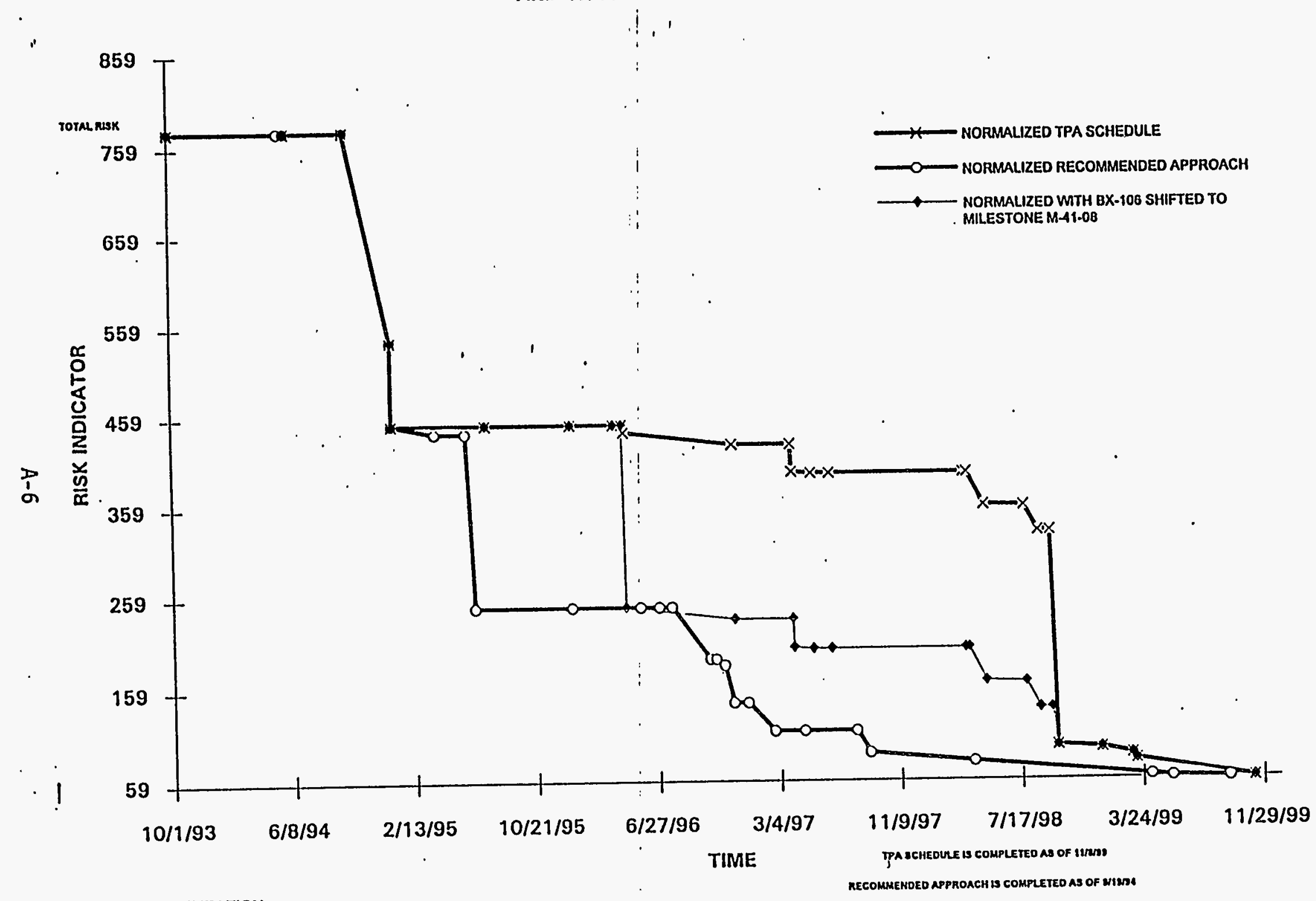


. TANK FARM NORMALIZED RISK vS PREPARATION TIME AND INTERIM STABILIZATION TIME

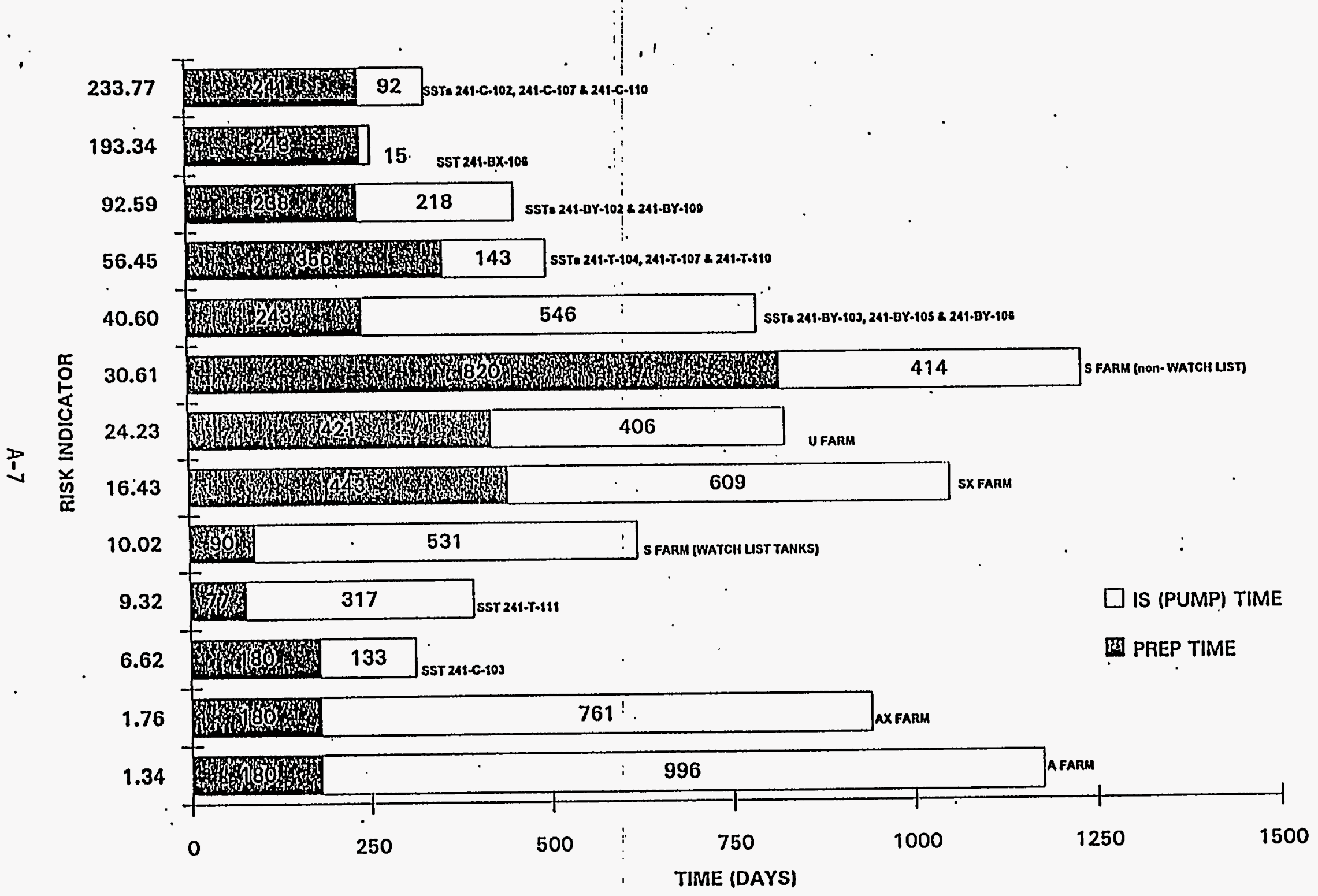




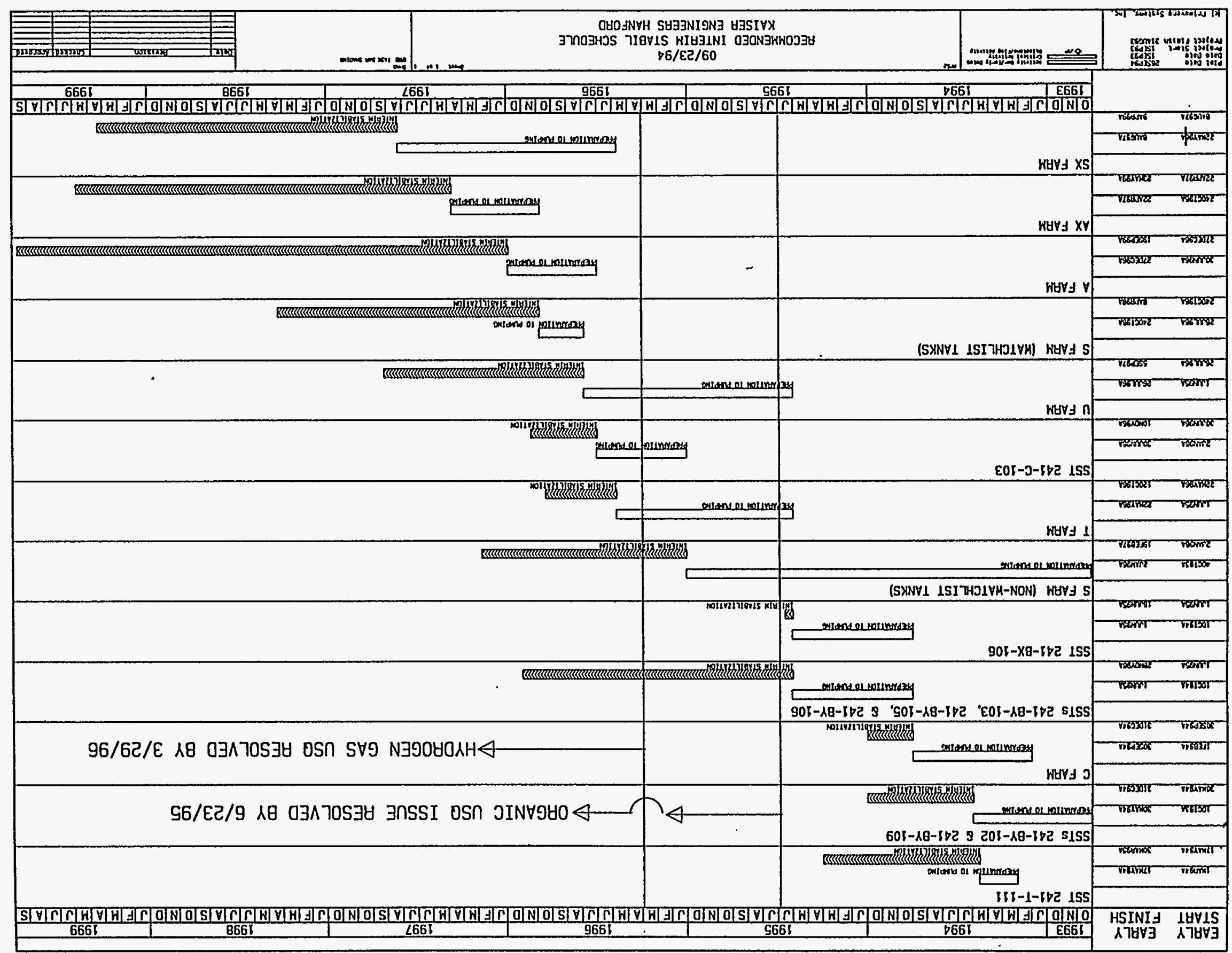




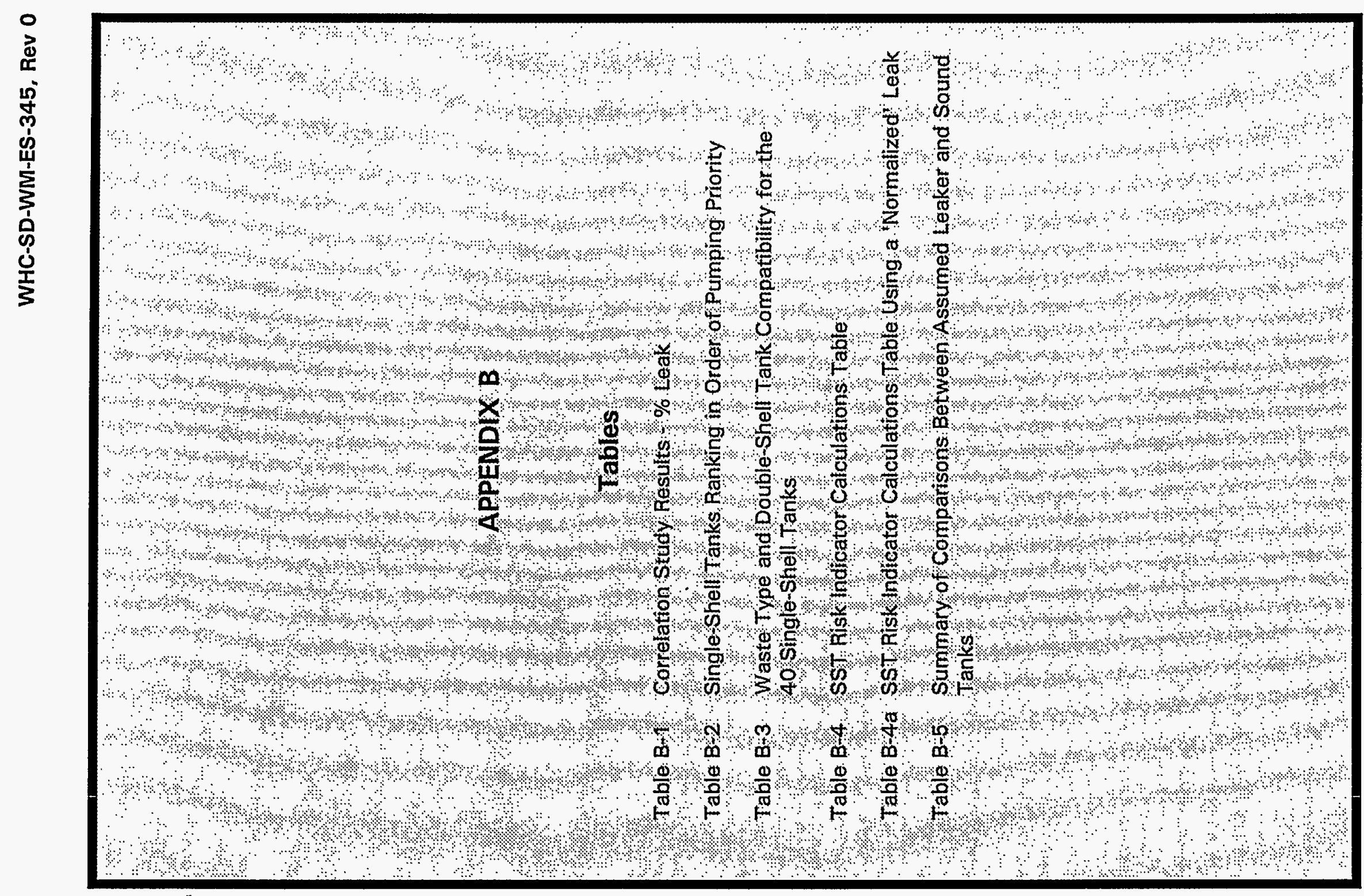


TABLE B-1

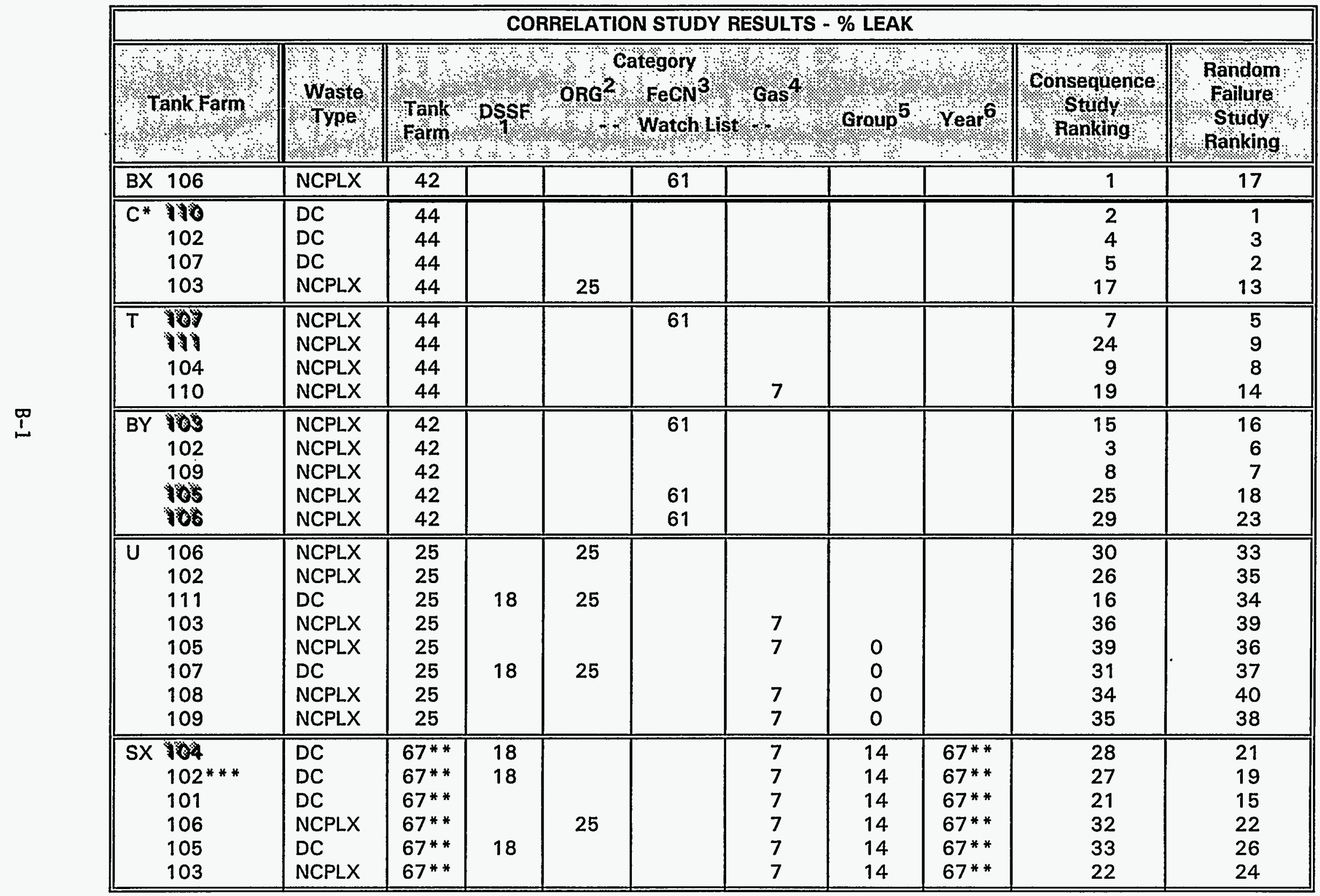


TABLE B-1 (Continued)

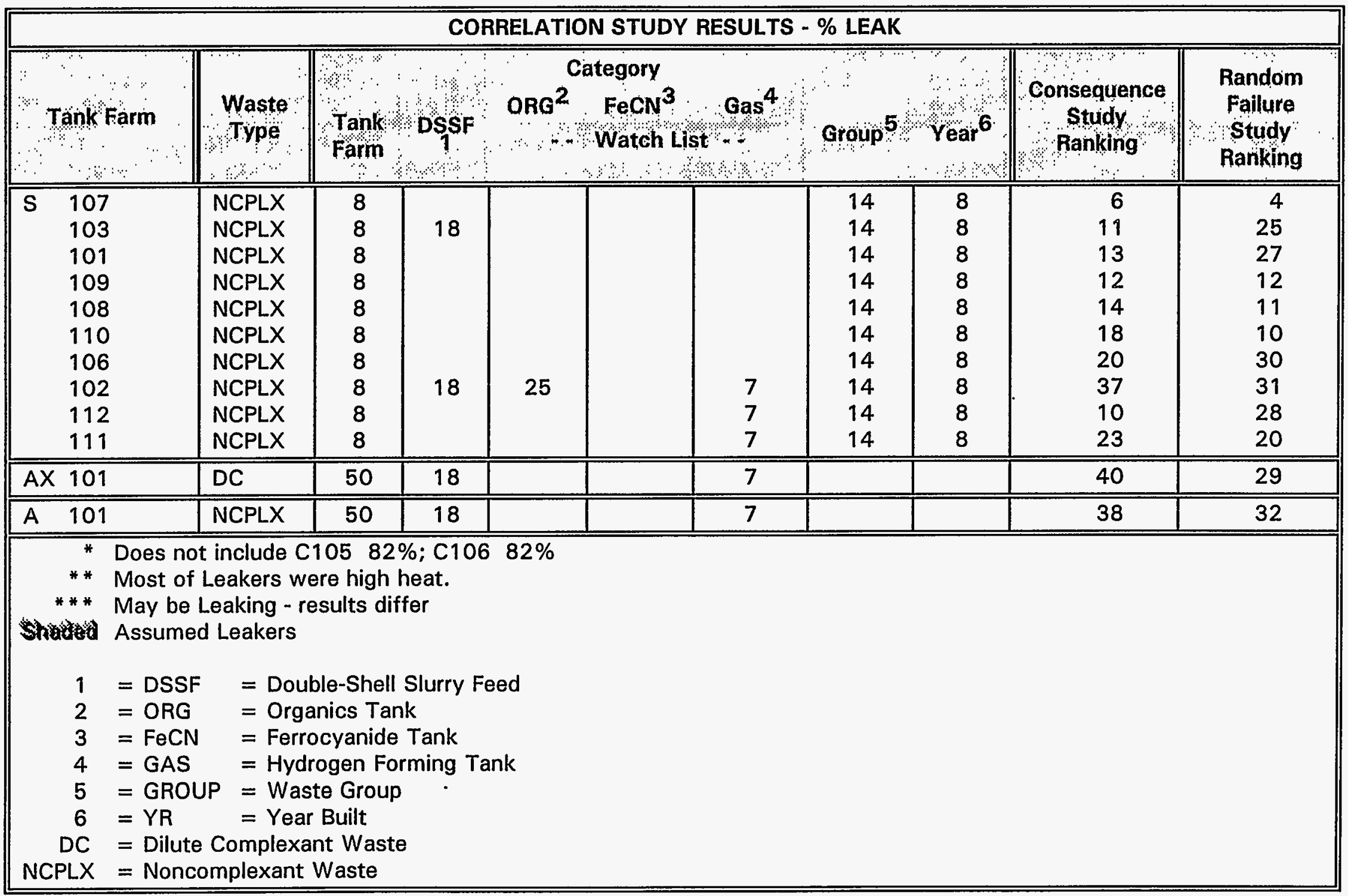


TABLE B-2

\begin{tabular}{|c|c|c|c|}
\hline \multicolumn{4}{|c|}{ SINGLE-SHELL TANKS RANKING IN ORDER OF PUMPING PRIORITY } \\
\hline Tank Number & $\begin{array}{l}\text { Pumping Tine } \\
\text { (ldays) }\end{array}$ & $\begin{array}{l}\text { Random Failure } \\
\text { Study Rank: }\end{array}$ & Consequence Study Rank \\
\hline$B X-106^{*}$ & 15 & 17 & 1 \\
\hline C-110 & 39 & 1 & 2 \\
\hline BY-102 & 292 & 6 & 3 \\
\hline C-102 & 93 & 3 & 4 \\
\hline C-107 & 95 & 2 & 5 \\
\hline S-107 & 123 & 4 & 6 \\
\hline T-107* & 33 & 5 & 7 \\
\hline BY-109 & 341 & 7 & 8 \\
\hline$T-104$ & 143 & 8 & 9 \\
\hline$S-112 *$ & 285 & 28 & 10 \\
\hline$S-103$ & 176 & 25 & 11 \\
\hline S-109 & 303 & 12 & 12 \\
\hline S-101 & 225 & 27 & 13 \\
\hline$S-108$ & 268 & 11 & 14 \\
\hline BY-103 & 350 & 16 & 15 \\
\hline$U-111$ & 253 & 34 & 16 \\
\hline C-103* & 133 & 13 & 17 \\
\hline$S-110$ & 265 & 10 & 18 \\
\hline T-110* & 115 & 14 & 19 \\
\hline S-106 & 414 & 30 & 20 \\
\hline $5 X-101 *$ & 320 & 15 & 21 \\
\hline $5 X-103^{*}$ & 557 & 24 & 22 \\
\hline S-111 & 20 & 20 & 23 \\
\hline T-111 & 148 & 9 & 24 \\
\hline BY $-105 *$ & 432 & 18 & 25 \\
\hline U-102 & 283 & 35 & 26 \\
\hline$S X-102^{*}$ & 452 & 19 & 27 \\
\hline
\end{tabular}


TABLE B-2 (Continued)

\begin{tabular}{|c|c|c|c|}
\hline \multicolumn{4}{|c|}{ SINGLE-SHELL TANKS RANKING IN ORDER OF PUMPING PRIORITY } \\
\hline $\begin{array}{l}\text { Tank Number } \\
\text { Uumber. }\end{array}$ & $\begin{array}{l}\text { Pumping tfine } \\
\text { (days) }\end{array}$ & $\begin{array}{l}\text { Randompailure } \\
\text { Study Rank }\end{array}$ & Cönsequence Stüdy Rank \\
\hline$S X-104^{*}$ & 500 & 21 & 28 \\
\hline BY-106* & 546 & 23 & 29 \\
\hline$U-106^{*}$ & 133 & 33 & 30 \\
\hline $\mathrm{U}-107^{*}$ & 349 & 37 & 31 \\
\hline$S X-106 *$ & 500 & 22 & 32 \\
\hline$S x-105^{*}$ & 609 & 26 & 33 \\
\hline $\mathrm{U}-108^{*}$ & 406 & 40 & 34 \\
\hline $\mathrm{U}-109^{*}$ & 379 & 38 & 35 \\
\hline$U-103^{*}$ & 404 & 39 & 36 \\
\hline S-102* & 531 & 31 & 37 \\
\hline$A-101^{*}$ & 996 & 32 & 38 \\
\hline U-105* & 343 & 36 & 39 \\
\hline$A X-101^{*}$ & 761 & 29 & 40 \\
\hline
\end{tabular}


TABLE B-3

\begin{tabular}{|c|c|c|c|}
\hline \multicolumn{4}{|c|}{$\begin{array}{l}\text { WASTE TYPE AND DOUBLE-SHELL TANK COMPATIBILITY FOR } \\
\text { THE } 40 \text { SINGLE-SHELL TANKS }\end{array}$} \\
\hline 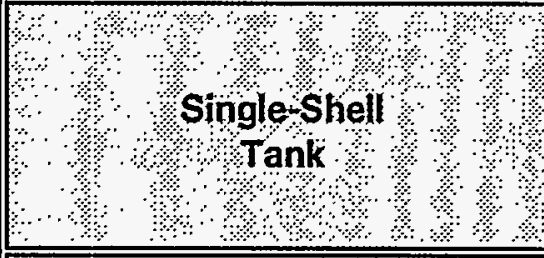 & $\begin{array}{l}\text { Q } \\
\text { Waste } \\
\text { Type } \\
\text { Ty }\end{array}$ & $\begin{array}{l}\text { Possibly } \\
\text { Compatible } \\
\text { Double-shell Tanks } \\
\text { cVolime in } \\
\text { Kilogallonsl }\end{array}$ & $\begin{array}{l}\text { Estimated liquid } \\
\text { Volume to be } \\
\text { Pumped } \\
\text { (Kilogallons) }\end{array}$ \\
\hline $\begin{array}{c}\text { A-101* } \\
\text { (Hydrogen) }\end{array}$ & NCPLX & $\begin{array}{rr}\text { AN-101 } & (500) \\
\text { AP-101 } & (79) \\
\text { AP-102 } & (33) \\
\text { AP-103 } & (7) \\
\text { AP-104 } & (1121) \\
\text { AP-105 } & (319) \\
\text { AP-106 } & (11) \\
\text { AP-107 } & (25) \\
\text { AP-108 } & (238) \\
\text { AW-102 } & (254) \\
\text { AW-103 } & (495) \\
\text { AW-104 } & (16) \\
\text { AW-105 } & (138) \\
\text { AW-106 } & (66) \\
\text { SY-102 } & (411)\end{array}$ & 390 \\
\hline \multicolumn{2}{|r|}{ Total } & (3394) & \\
\hline $\begin{array}{l}\text { AX-101* } \\
\text { (Hydrogen) }\end{array}$ & $D C$ & $\begin{array}{rr}\text { AN-102 } & (39) \\
\text { AN-107 } & (72) \\
\text { AY-102 } & (131)\end{array}$ & 298 \\
\hline \multicolumn{2}{|r|}{ Total } & (242) & \\
\hline $\begin{array}{c}\text { BX-106* } \\
\text { (Ferrocyanide) }\end{array}$ & NCPLX & Same as A-101 & 15 \\
\hline BY -102 & NCPLX & Same as $B X-106$ & 22 \\
\hline $\begin{array}{l}\text { BY-103* } \\
\text { (Ferrocyanide) }\end{array}$ & NCPLX & Same as $B X-106$ & 137 \\
\hline $\begin{array}{l}\text { BY-105* } \\
\text { (Ferrocyanide) }\end{array}$ & NCPLX & Same as $B X-106$ & 169 \\
\hline $\begin{array}{l}\text { BY-106* } \\
\text { (Ferrocyanide) }\end{array}$ & NCPLX & Same as $B X-106$ & 213 \\
\hline$B Y-109$ & NCPLX & Same as $B X-106$ & 57 \\
\hline$C-102$ & $D C$ & Same as $A X-101$ & 19 \\
\hline $\begin{array}{c}\text { C-103* } \\
\text { (Organic Salts) }\end{array}$ & NCPLX & Same as $B X-106$ & 133 \\
\hline$C-107$ & $D C$ & Same as $A X-101$ & 20 \\
\hline
\end{tabular}


TABLE B-3 (Continued)

\begin{tabular}{|c|c|c|c|}
\hline \multicolumn{4}{|c|}{$\begin{array}{l}\text { WASTE TYPE AND DOUBLE-SHELL TANK COMPATIBILITY FOR } \\
\text { THE } 40 \text { SINGLE-SHELL TANKS }\end{array}$} \\
\hline $\begin{array}{ccc} & \\
& & \\
& & \\
& & \end{array}$ & Waste & $\begin{array}{l}\text { Possibly } \\
\text { Compatible } \\
\text { Doublesshellonanks } \\
\text { Uvolume: in } \\
\text { Kilogallons) }\end{array}$ & $\begin{array}{l}\text { Estimated Liquid } \\
\text { Yolume to be } \\
\text { Pumped } \\
\text { (Kilogällons) }\end{array}$ \\
\hline C-110 & $D C$ & Same as $A X-101$ & 5 \\
\hline S-101 & NCPLX & Same as $B X-106$ & 90 \\
\hline $\begin{array}{c}\text { S-102* } \\
\text { (Hydrogen, Organic Salts) }\end{array}$ & NCPLX & Same as $A-101$ & 208 \\
\hline S-103 & NCPLX & Same as $\mathrm{A}-101$ & 79 \\
\hline S-106 & NCPLX & Same as $B X-106$ & 162 \\
\hline S-107 & NCPLX & Same as BX-106 & 44 \\
\hline S-108 & NCPLX & Same as BX-106 & 105 \\
\hline S-109 & NCPLX & Same as $B X-106$ & 119 \\
\hline S-110 & NCPLX & Same as $B X-106$ & 103 \\
\hline $\begin{array}{c}\text { S-111* } \\
\text { (Hydrogen) }\end{array}$ & NCPLX & Same as $\mathrm{BX}-106$ & 134 \\
\hline $\begin{array}{c}\text { S-112* } \\
\text { (Hydrogen) }\end{array}$ & NCPLX & Same as BX-106 & 112 \\
\hline $\begin{array}{l}\mathrm{SX}-101^{*} \\
\text { (Hydrogen) }\end{array}$ & DC & Same as $A X-101$ & 124 \\
\hline $\begin{array}{l}\mathrm{SX}-102^{*} \\
\text { (Hydrogen) }\end{array}$ & $D C$ & Same as A-101 & 177 \\
\hline $\begin{array}{l}\mathrm{SX}-103^{*} \\
\text { (Hydrogen) }\end{array}$ & NCPLX & Same as $B X-106$ & 211 \\
\hline $\begin{array}{l}\text { SX-104* } \\
\text { (Hydrogen) }\end{array}$ & DC & Same as A-101 & 195 \\
\hline $\begin{array}{l}\text { SX-105* } \\
\text { (Hydrogen) }\end{array}$ & DC & Same as $A-101$ & 238 \\
\hline $\begin{array}{l}\text { SX-106* } \\
\text { (Hydrogen, Organic Salts) }\end{array}$ & NCPLX & Same as $\mathrm{BX}-106$ & 233 \\
\hline$T-104$ & NCPLX & Same as $\mathrm{BX}-106$ & 44 \\
\hline $\begin{array}{l}\text { T-107* } \\
\text { (Ferrocyanide) }\end{array}$ & NCPLX & Same as $B X-106$ & 16 \\
\hline $\begin{array}{c}\text { T-110* } \\
\text { (Hydrogen) }\end{array}$ & NCPLX & Same as $B X-106$ & 36 \\
\hline
\end{tabular}


TABLE B-3 (Continued)

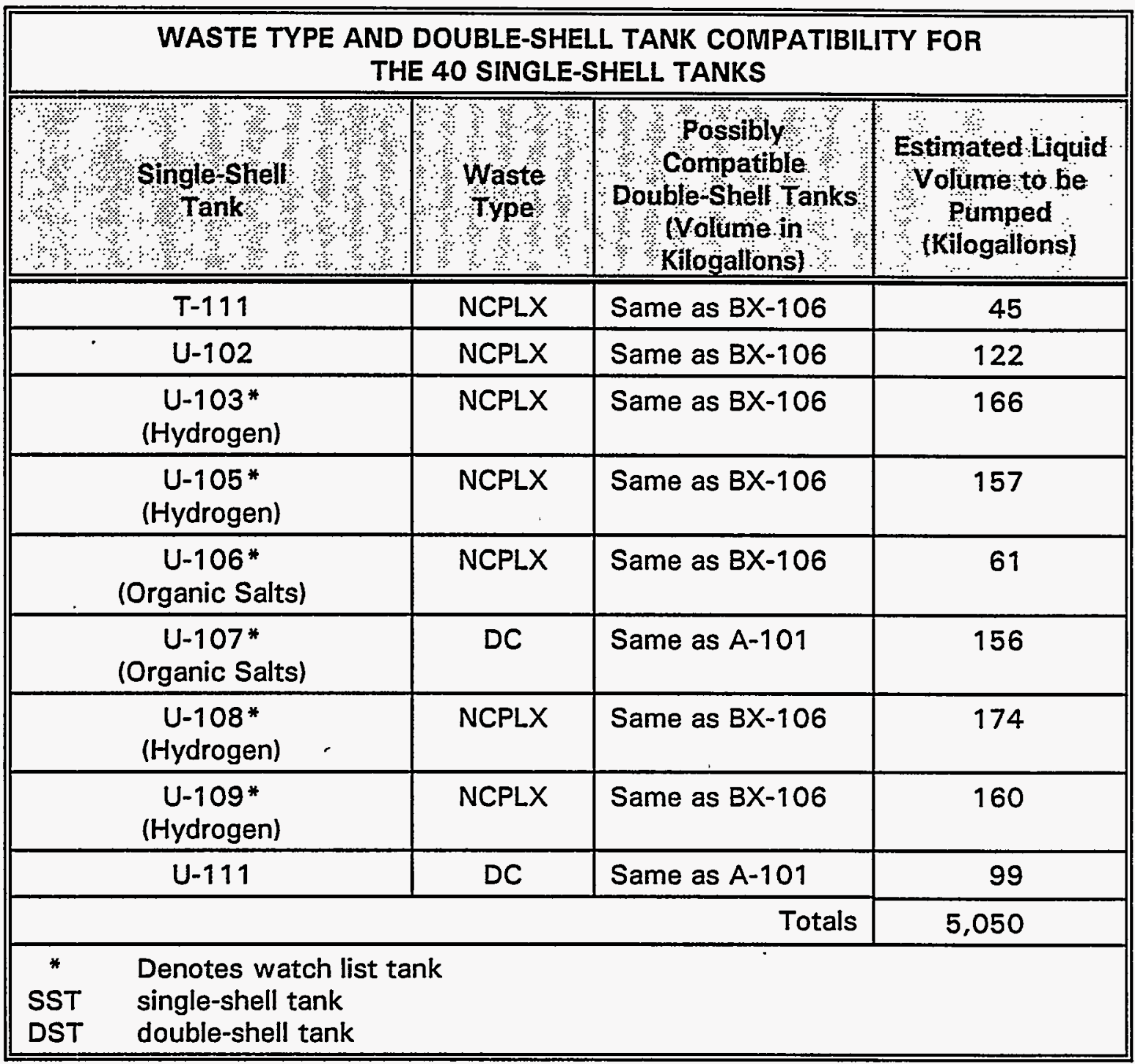


TABLE B. 4

SST RISK INDICATOR CALCULATIONS TABLE

\begin{tabular}{|c|c|c|c|c|c|c|c|c|c|}
\hline sst & $\begin{array}{c}\text { TANK } \\
\text { CONSEQUENCE PEN } \\
\text { KGAL } \\
\text { (CI) }\end{array}$ & $\begin{array}{c}\text { TANK } \\
\text { CONSEQUENCE PER } \\
\text { TANK VOLUME } \\
\text { (C) }\end{array}$ & $\begin{array}{c}\text { FAILURE } \\
\text { PMOPENSITY } \\
\text { (PI) }\end{array}$ & 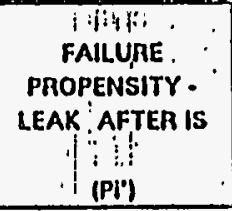 & $\begin{array}{l}\text { TANK RISK } \\
\text { PER KGAL } \\
\\
\text { (CIPPI) }\end{array}$ & $\begin{array}{c}\text { TANK RISK } \\
\text { PER TANK } \\
\text { VOLUME } \\
. \\
\text { (CiePi) } \\
\end{array}$ & $\begin{array}{l}\text { TANK RISK } \\
\text { AFTER IS } \\
\text { PER TANK } \\
\text { VOLUME } \\
\text { (CI'P(')'3 } \\
\end{array}$ & $\begin{array}{l}\text { TOTAL } \\
\text { PUMPADLE } \\
\text { VOLUME } \\
\text { IKGALI }\end{array}$ & sst \\
\hline$B \times \cdot 10 B$ & 60.07 & 1000 & 0.01 & 0.05 & 40.07 & 010 & 10.00 & 15 & $B X-10 B$ \\
\hline BY.103" & 0.57 & 900 & 0.01 & 0.05 & 4.01 & 549 & 0.80 & 137 & $0 \mathrm{Y} .103^{\circ}$ \\
\hline BY.106. & 4.14 & 700 & 0.01 & 0.05 & 2.63 & 127 & 0.02 & 109 & BY. $105^{\circ}$ \\
\hline $0 Y .100^{\circ}$ & 3.20 & 700 & 0.01 & 0.05 & 2.01 & 127 & 0.40 & 21.7 & $B Y .100^{\circ}$ \\
\hline$n Y \cdot 102$ & 31.01 & 700 & 0.15 & 0.05 & 11.31 & 315 & 1.77 & 22 & IIY. 102 \\
\hline OY. 100 & 12.28 & 700 & 0.15 & 10.05 & 6.53 & 315 & 1.84 & 67 & BY.100 \\
\hline C. 102 & 20.32 & 800 & 0.15 & 0.05 & 11.01 & 225 & 3.05 & 18 & 6.102 \\
\hline C.107 & 26 & 600 & 0.16 & 10.05 & 11.25 & 225 & 3.75 & 2.0 & 5.107 \\
\hline U.102 & 1.1 & 500 & 0.46 & 0.05 & 1.05 & 225 & 0.02 & 122 & 0.102 \\
\hline C.103 & 0.02 & 800 & 0.26 & 10.05 & 1.61 & 200 & 0.00 & 133 & C.103 \\
\hline$T .104$ & 0.00 & 100 & 0.45 & 0.05 & 4.00 & 100 & 1.30 & 44 & T.104 \\
\hline $5 x \cdot 100$ & 3 & 700 & 0.26 & 0.05 & 0.76 & 175 & 0.45 & 233 & $5 x \cdot 100$ \\
\hline 11.111 & 0.00 & BOO & 0.26 & $\because 0.05$ & 1.62 & 150 & 0.01 & 08 & 11.111 \\
\hline $5 x \cdot 103$ & 4.74 & 1000 & 0.11 & 0.05 & 0.00 & 110 & 0.71 & 211 & $5 x-103$ \\
\hline 5.112 & 0.93 & 1000 & 0.11 & 0.05 & 1.25 & 140 & 1.34 & 112 & 5.112 \\
\hline C.110" & 60 & 300 & 0.45 & 0.05 & 27.00 & 135 & 8.00 & 5 & C.110 \\
\hline $5 \times .104^{\circ}$ & 3.60 & 700 & 0.18 & 0.05 & 0.05 & 120 & 0.54 & 105 & $5 \times \cdot 104^{\circ}$ \\
\hline $5 x \cdot 102^{\circ}$ & 3.05 & 700 & 0.18 & 0.05 & 0.71 & 120 & 0.59 & 177 & $5 \times \cdot 102^{\circ}$ \\
\hline $5 x-106$ & 2.94 & 700 & 0.18 & 0.05 & 0.53 & 120 & 0.11 & 230 & $5 \times \cdot 105$ \\
\hline 5.109 & $7.5 B$ & 000 & 0.14 & 0.05 & 1.00 & 120 & 1.13 & 110 & S.109 \\
\hline$A X-101$ & 2.35 & 700 & 0.18 & 0.05 & 0.12 & 120 & 0.35 & 298 & $A x-101$ \\
\hline$A=101$ & 1.70 & 700 & 0.10 & 0.05 & 0.32 & 120 & 0.27 & 390 & A.101 \\
\hline U.107 & 3.21 & 600 & 0.26 & 0.05 & 0.00 & 125 & 0.10 & 150 & 0.107 \\
\hline $5 \cdot 102$ & 2.4 & 600 & 0.25 & 0.05 & 0.00 & 125 & $0.30^{\circ}$ & 200 & 5.102 \\
\hline$T \cdot 107^{\circ}$ & 12.5 & 200 & 0.01 & 0.05 & 7.03 & 122 & $1.0 n$ & 10 & $T .107^{\circ}$ \\
\hline S.100 & 4.04 & 800 & 0.14 & 0.05 & 0.00 & 112 & 0.74 & 162 & S. 100 \\
\hline S.103 & 7.59 & 000 & 0.18 & 0.05 & 1.37 & 108 & 1.14 & 79 & 5.103 \\
\hline S.108 & 0.07 & 700 & 0.14 & 10.05 & 0.03 & 98 & 1.00 & 105 & S.108 \\
\hline T.1111" & 4.44 & 200 & 0.15 & 0.05 & 2.00 & 00 & 0.07 & 45 & $T-111^{\circ}$ \\
\hline$s x-101$ & 1.81 & 000 & 0.14 & 0.05 & $0.0 n$ & 04 & 0.73 & 121 & $5 \times \cdot 101$ \\
\hline 5.107 & 13.01 & 000 & 0.14 & 10.05 & 1.01 & $B A$ & 2.05 & 44 & 5.107 \\
\hline 5.101 & 0.07 & 000 & 0.11 & 0.05 & 0.03 & BA & 1.00 & 90 & S.101 \\
\hline 5.110 & 5.83 & 000 & 0.14 & 0.05 & 0.02 & B4 & 0.87 & 103 & S.110 \\
\hline 5.111. & 4.48 & 000 & 0.14 & 10.05 & 0.03 & B4 & 0.07 & 134 & 5.111 \\
\hline 0.100 & 3.20 & 200 & 0.25 & 0.05 & 0.02 & 50 & 0.49 & 61 & 0.100 \\
\hline U.108 & 2.87 & 500 & 0.07 & 10.05 & 0.20 & 35 & 0.43 & 174 & U.108 \\
\hline U.103 & 2.41 & 400 & 0.07 & 0.05 & 0.17 & 28 & 0.30 & 100 & U.103 \\
\hline 11.100 & 2.5 & 400 & 0.07 & 0.05 & 0.18 & 20 & 0.30 & 100 & U. 109 \\
\hline$T .110$ & 5.50 & 200 & 0.07 & $i 0.05$ & 0.39 & 14 & 0.03 & 30 & $T .110$ \\
\hline 11.105 & 1.27 & 200 & 0.07 & 10.05 & 0.00 & 11 & 0.18 & 157 & 11.105 \\
\hline
\end{tabular}

IS - INTERIM STADILIZATION

TOTAL NISK PER KGAL = 155.20

TOTAL NISK PER TANK VOLUME $=0563$ 


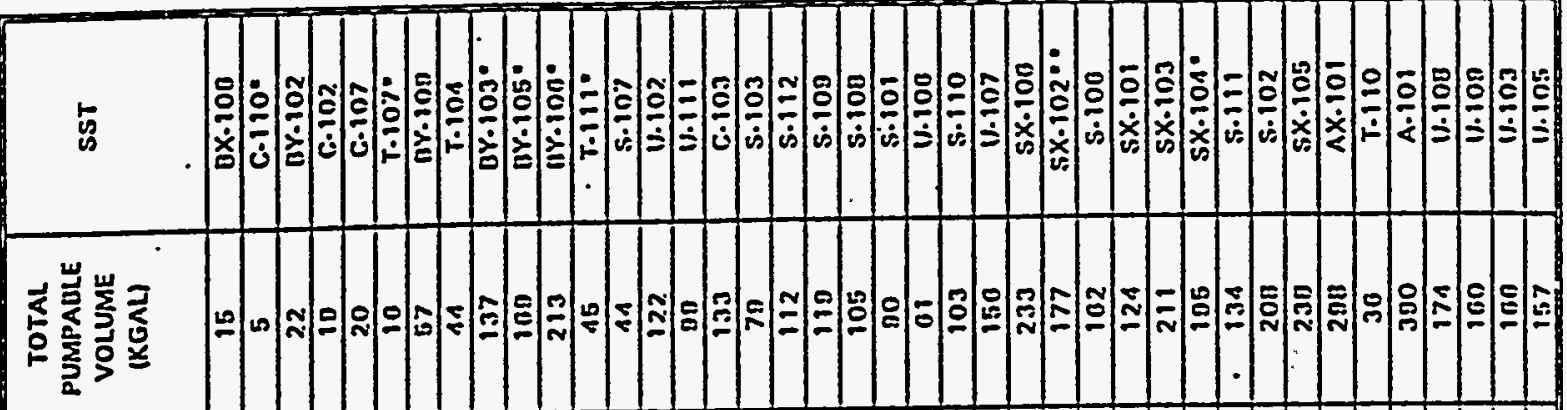

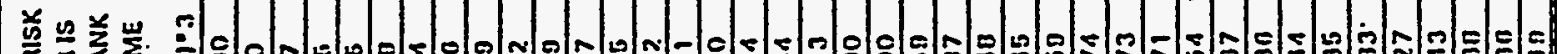

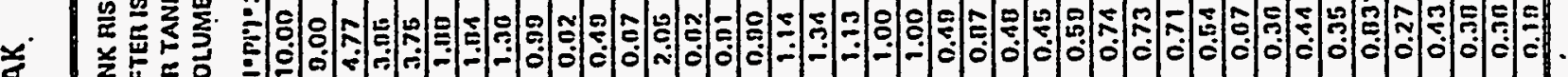

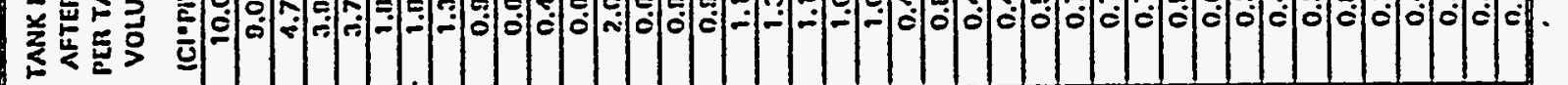

-

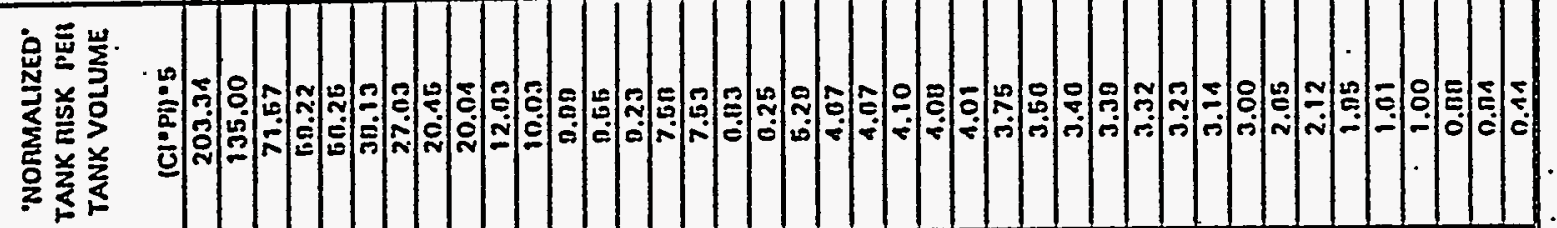

美范

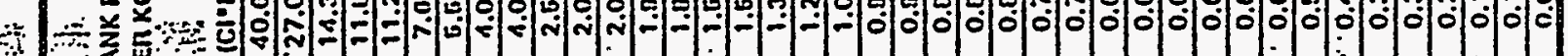

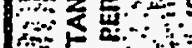

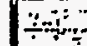

닐.

至

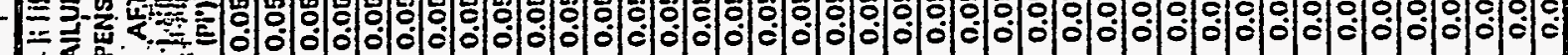


TABLE B-5

\begin{tabular}{|c|c|c|c|}
\hline \multicolumn{4}{|c|}{ SUMMARY OF COMPARISONS BETWEEN ASSUMED LEAKER AND SOUND TANKS } \\
\hline $\begin{array}{l}\text { Integrity by } \\
\text { Characteristic }\end{array}$ & \multirow{2}{*}{$\frac{\text { Correlation }}{0.523}$} & \multirow[t]{2}{*}{ \& 8 \& comment } & \multirow[b]{2}{*}{$\begin{array}{r}14 \% \text { leaked } \\
100 \% \text { leaked } \\
0 \% \text { leaked } \\
100 \% \text { leaked }\end{array}$} \\
\hline $\begin{array}{l}\text { Group }(1-30) * \\
\text { - SORWT Study }\end{array}$ & & & \\
\hline $\begin{array}{l}\text { Last Waste Added, * } \\
\text { Years Ago }\end{array}$ & 0.397 & $\begin{array}{l}20 \text { tanks with last waste added } \\
21 \text { to } 25 \text { years ago }\end{array}$ & $80 \%$ leaked \\
\hline Watch List (WL) * & 0.333 & $\begin{array}{l}15 \text { gas tank } \\
11 \text { Hi-Heat tanks }\end{array}$ & $\begin{array}{r}7 \% \text { leaked } \\
82 \% \text { leaked }\end{array}$ \\
\hline $\operatorname{Farm}(A-U, 12)$ & 0.326 & \multicolumn{2}{|c|}{$\begin{array}{l}\text { Farm }^{1} \\
\% \text { Lk. } \frac{T Y}{83} \\
\frac{S X}{67}\end{array} \frac{B}{62} \frac{A \& A X}{50} \frac{T X, C, \& T}{44} \frac{B X}{42} \frac{B Y}{42} \frac{U}{25} \frac{S}{8}$} \\
\hline Built 1944-1964 & 0.30 & $\begin{array}{|lc|}1951 & 72 \text { tanks } \\
1952^{1} & 6 \text { tanks (TY farm built by SCO) } \\
1954 & 15 \text { tanks } \\
\end{array}$ & $\begin{array}{r}8 \% \text { leaked } \\
83 \% \text { leaked } \\
67 \% \text { leaked } \\
\end{array}$ \\
\hline Waste Type & 0.200 & $\begin{array}{l}\text { DSSF } 11 \text { tanks } \\
\text { other } \quad 8 \text { tanks }\end{array}$ & $\begin{array}{l}18 \% \text { leaked } \\
25 \% \text { leaked }\end{array}$ \\
\hline $\begin{array}{l}\text { Subcontractor: \# } \\
\text { MK, Other, SCO }\end{array}$ & 0.156 & $\mathrm{SCO}^{1}$ built 6 tanks in 1952 & $83 \%$ leaked \\
\hline $\begin{array}{l}\text { Knuckle Size } \\
0,6,36,48^{\prime \prime}\end{array}$ & 0.140 & 21 tanks with no knuckle & $62 \%$ leaked \\
\hline $\begin{array}{l}\text { Tank Capacity: Kgal \# } \\
55,535,758,1000\end{array}$ & 0.139 & 48 tanks with $758 \mathrm{Kgal}$ capacity & $39.6 \%$ leaked \\
\hline $\begin{array}{l}\text { Knuckle Fab \# } \\
\text { (GB, Other) }\end{array}$ & 0.057 & & \\
\hline $\begin{array}{l}\text { Steel Type: } \# \\
\text { B, F, P, S }\end{array}$ & 0.05 & & \\
\hline $\begin{array}{l}\text { Tank Bottom Dish \# } \\
\left(0,6,12^{\prime \prime}\right)\end{array}$ & 0.028 & & \\
\hline $\begin{array}{l}\text { Main Contractor: \# } \\
\text { DuPont GE }\end{array}$ & 0.021 & & \\
\hline \multicolumn{4}{|c|}{$\begin{array}{l}\text { * Characteristic is significantly related to integrity. } \\
\text { Characteristic may be related to integrity. } \\
\text { \# Characteristic shows little or no relationship to integrity. } \\
1 \text { These tanks are in the TY farm and were built in } 1952 \text { by SCO. } \\
\text { They also, contained high heat waste. }\end{array}$} \\
\hline
\end{tabular}




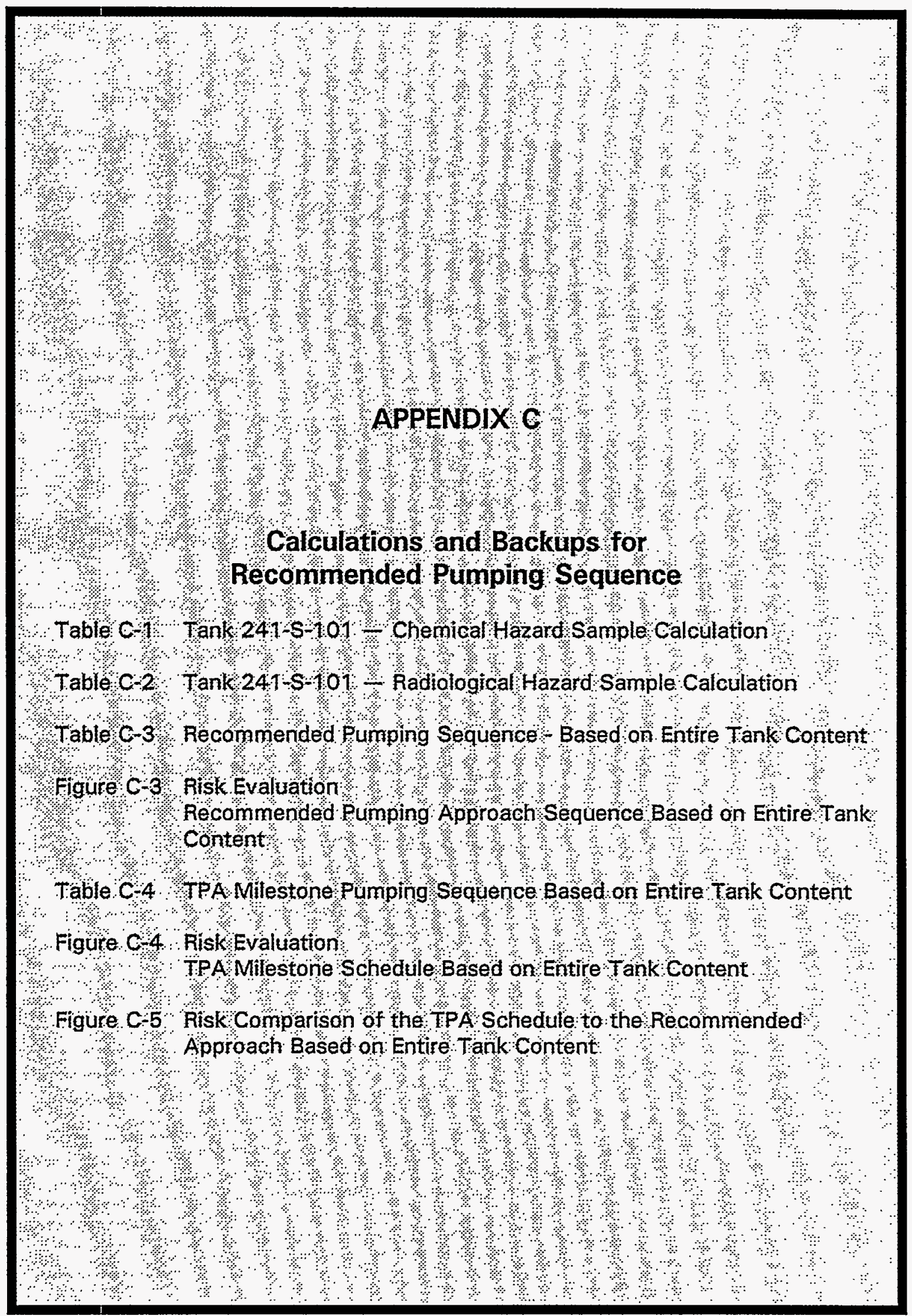


TABLE C-1

\begin{tabular}{|c|c|c|c|c|c|}
\hline \multicolumn{6}{|c|}{ TANK 241-S-101 - CHEMICAL HAZARD SAMPLE CALCULATION } \\
\hline Element symbol & Element Name & $\mathrm{CF}$ & WF: & Amount & Total \\
\hline $\mathrm{Ag}$ & Silver & $\mathrm{C}$ & 0.001 & 0 & 0 \\
\hline $\mathrm{Al}(\mathrm{OH}) 4$ & Aluminum Hydroxide & $D$ & 0.0002 & 0 & 0 \\
\hline As & Arsenic & $x$ & 1.0 & 0 & 0 \\
\hline$B$ & Boron & $D$ & 0.0002 & 0 & 0 \\
\hline $\mathrm{Be}$ & Beryllium & A & 0.1 & 0 & 0 \\
\hline $\mathrm{C} 2 \mathrm{H} 3 \mathrm{O} 2$ & Acetate & C & 0.001 & $1.5 E 4$ & $1.5 \mathrm{E} 1$ \\
\hline $\mathrm{C} 6 \mathrm{H} 507$ & Citerate & C & 0.001 & $1.7 \mathrm{E7}$ & $1.7 \mathrm{E} 4$ \\
\hline $\mathrm{CN}$ & Cyanide & A & 0.1 & 0 & 0 \\
\hline $\mathrm{CO} 3$ & Carbonate & B & 0.01 & $1.2 \mathrm{E7}$ & $1.2 \mathrm{E} 5$ \\
\hline $\mathrm{C} 204$ & Oxalate & A & 0.1 & 0 & 0 \\
\hline $\mathrm{Ca}$ & Calcium & $A$ & 0.1 & 0 & 0 \\
\hline $\mathrm{Cd}$ & Cadmium & A & 0.1 & 0 & 0 \\
\hline $\mathrm{Cl}$ & Chlorine & A & 0.1 & 0 & 0 \\
\hline $\mathrm{Cr}$ & Chromium & $D$ & 0.0002 & $4.2 \mathrm{E7}$ & 8.4E3 \\
\hline $\mathrm{Cu}$ & Copper & $D$ & 0.0002 & 0 & 0 \\
\hline EDTA & Organic Complexant & $x$ & 1.0 & $8.8 E 4$ & 8.8E4 \\
\hline$F$ & Fluorine & A & 0.1 & $1.9 \mathrm{E5}$ & $1.9 \mathrm{E} 4$ \\
\hline $\mathrm{Fe}$ & Iron & $\mathrm{C}$ & 0.001 & $3.4 \mathrm{E} 6$ & $3.4 \mathrm{E3}$ \\
\hline $\mathrm{Fe}(\mathrm{CN}) 6$ & Ferrocyanide & $x$ & 1.0 & $2.1 \mathrm{E3}$ & $2.1 \mathrm{E3}$ \\
\hline HEDTA & Organic Complexant & $x$ & 1.0 & 1.7E5 & 1.7E5 \\
\hline $\mathrm{Hg}$ & Mercury & $x$ & 1.0 & 0 & 0 \\
\hline$K$ & Potassium & A & 0.1 & $1.2 \mathrm{E} 6$ & $1.2 \mathrm{E} 5$ \\
\hline La & Lanthanum & C & 0.001 & 0 & 0 \\
\hline $\mathrm{Mg}$ & Magnesium & C & 0.001 & 0 & 0 \\
\hline $\mathrm{Mn}$ & Manganese & C & 0.001 & $3.3 E 4$ & $3.3 E 1$ \\
\hline Mo & Molybdenum & $\mathrm{C}$ & 0.001 & 0 & 0 \\
\hline $\mathrm{NH3}$ & Ammonia & B & 0.01 & 0 & 0 \\
\hline NO2 & Nitrite & B & 0.01 & $9.2 \mathrm{E} 6$ & $9.2 \mathrm{E} 4$ \\
\hline NO3 & Nitrate & $B$ & 0.01 & $7.4 \mathrm{E} 8$ & $7.4 \mathrm{E} 6$ \\
\hline $\mathrm{Na}$ & Sodium & A & 0.1 & $2.8 \mathrm{E} 8$ & $2.8 E 7$ \\
\hline $\mathrm{NaAlO} 2$ & Sodium Aluminate & $B$ & 0.01 & 0 & 0 \\
\hline $\mathrm{Na} 2 \mathrm{CO} 3$ & Sodium Carbonate & B & 0.01 & 0 & 0 \\
\hline NaNO2 & Sodium Nitrite & B & 0.01 & 0 & 0 \\
\hline NaNO3 & Sodium Nitrate & B & 0.01 & 0 & 0 \\
\hline
\end{tabular}


TABLE C-1 (Continued)

\begin{tabular}{|c|c|c|c|c|c|}
\hline \multicolumn{6}{|c|}{ TANK 241-S-101 - CHEMICAL HAZARD SAMPLE CALCULATION } \\
\hline Element Symbols & - Element Name & $\mathrm{CF}$ & WF & Amount & $\therefore$ Total \\
\hline $\mathrm{NaOH}$ & Sodium Hydroxide & $\mathrm{C}$ & 0.001 & 0 & 0 \\
\hline $\mathrm{Na3PO4}$ & Sodium Phosphate & $\mathrm{D}$ & 0.0002 & 0 & 0 \\
\hline $\mathrm{Na2SO} 4$ & Sodium Tetra-Sulfate & $D$ & 0.0002 & 0 & 0 \\
\hline $\mathrm{Ni}$ & Nickel & B & 0.01 & $4.1 \mathrm{E} 4$ & $4.1 \mathrm{E} 2$ \\
\hline $\mathrm{OH}$ & Hydroxide & C & 0.001 & $1.7 \mathrm{E} 8$ & 1.7E5 \\
\hline $\mathbf{P}$ & Phosphorus & $\mathrm{D}$ & 0.0002 & 0 & 0 \\
\hline PO4 & Phosphate & $D$ & 0.0002 & $1.9 \mathrm{E} 6$ & $3.8 \mathrm{E} 2$ \\
\hline $\mathrm{Pb}$ & Lead & $x$ & 1.0 & $4.2 \mathrm{E} 2$ & $4.2 \mathrm{E} 2$ \\
\hline $\mathrm{Pd}$ & Palladium & $\mathrm{C}$ & 0.001 & 0 & 0 \\
\hline $\mathrm{Re}$ & Rhenium & $\mathrm{C}$ & 0.001 & 0 & 0 \\
\hline $\mathrm{S}$ & Sulfur & $\bar{C}$ & 0.001 & 0 & 0 \\
\hline SO4 & Sulfate & $B$ & 0.01 & $4.8 \mathrm{E} 6$ & $4.8 \mathrm{E} 4$ \\
\hline $\mathrm{Sb}$ & Antimony & $\bar{D}$ & 0.0002 & 0 & 0 \\
\hline $\mathrm{Se}$ & Selenium & $B$ & 0.01 & 0 & 0 \\
\hline $\mathrm{SeO} 4$ & Selerate & $B$ & 0.01 & 0 & 0 \\
\hline Si & Silicon & $\mathrm{C}$ & 0.001 & 0 & 0 \\
\hline $\mathrm{SiO} 3$ & Silicate & $D$ & 0.0002 & $7.6 \mathrm{E} 5$ & $1.5 \mathrm{E} 2$ \\
\hline Sn & Tin & $A$ & 0.1 & 0 & 0 \\
\hline TOC & Total Organic Content & $x$ & 1.0 & 0 & 0 \\
\hline \multirow[t]{2}{*}{ Th } & Thorium & $D$ & 0.0002 & 0 & 0 \\
\hline & & & & TOTAL $\times 10$ & $3.6 \mathrm{E} 8$ \\
\hline \multicolumn{6}{|c|}{$\begin{array}{l}\text { This table shows the elements/compounds that were found in some or all of the tanks } \\
\text { on the Hanford Site. A table like this was completed for each tank that is to be } \\
\text { interim stabilized. This is the calculation that was performed for tank S-101. In this } \\
\text { calculation all of the weights of the elements/compounds are input into this table. } \\
\text { Each chemical is assigned a chemical hazard factor (CF) with } X \text { being the most } \\
\text { hazardous and D being the least hazardous. The weighing factor (WF) associated } \\
\text { with the hazard factor is then multiplied by the amount of each element/compound } \\
\text { present. Then the amounts of all the elements/ compounds is added together to } \\
\text { come up with a total. This total is then multiplied by a factor of } 10 \text { to make up for } \\
\text { data inconsistencies, etc. The grand total is then assigned to the tank and will be } \\
\text { ranked accordingly when all of the data is complete for each tank. }\end{array}$} \\
\hline
\end{tabular}


TABLE C-2

\begin{tabular}{|c|c|c|c|c|c|}
\hline \multicolumn{6}{|c|}{ TANK 241-S-101 - RADIOLOGICAL HAZARD SAMPLE CALCULATION } \\
\hline Radionuclide & $\begin{array}{c}\text { Content } \\
\text { (Bq) }\end{array}$ & $\begin{array}{l}\text { Content } \\
\text { (Ci) }\end{array}$ & $\begin{array}{c}\text { Half-Life } \\
(y=\text { year, } d=\text { day, } h=\text { hour })\end{array}$ & $\begin{array}{c}\text { Applicable } \\
\text { Multiplying } \\
\text { Factor }\end{array}$ & Score \\
\hline$\overline{C 14}$ & $1.9 \mathrm{E}+12$ & 51.3 & $5730 y$ & 1000 & 2000 \\
\hline Co60 & 0 & 0 & $5.263 y$ & $\overline{0}$ & 0 \\
\hline Se79 & $2.2 E+11$ & 5.94 & $65000 y$ & 1000 & 2000 \\
\hline Sr89/90 & $2.0 \mathrm{E}+16$ & 540000 & $27.7 y$ & 10000 & 20000 \\
\hline Y90 & $2.0 E+16$ & 540000 & $64 \mathrm{~h}$ & 1000 & 2000 \\
\hline Zr95 & 0 & 0 & $65.5 d$ & 0 & 0 \\
\hline$\overline{T c 99}$ & $7.4 \mathrm{E}+12$ & 199.8 & $212000 y$ & 1000 & 2000 \\
\hline Ru/Rh106 & $4.1 E+06$ & .000111 & $368 d$ & 10 & 20 \\
\hline Sb125 & 0 & $\overline{0}$ & $2.71 y$ & 0 & 0 \\
\hline 1129 & $1.1 E+10$ & .297 & $1.7 E+07 y$ & 100 & 200 \\
\hline Cs134 & 0 & 0 & $2.046 y$ & 0 & 0 \\
\hline Cs137 & $3.3 E+15$ & 89100 & $30 y$ & 1000 & 2000 \\
\hline Ce144 & 0 & 0 & $284 d$ & 0 & 0 \\
\hline Pm147 & 0 & 0 & $2.62 y$ & 0 & 0 \\
\hline Eu154/155 & 0 & 0 & $16 y$ & 0 & 0 \\
\hline U-Nat & $7.4 E+10$ & 1.998 & $4.51 E+09 y$ & 1000 & 2000 \\
\hline Np237 & $3.7 E+09$ & 0.0999 & $2.14 E+06 y$ & 100 & 200 \\
\hline Pu238 & $3.7 E+11$ & 9.99 & $86.4 y$ & 100 & 200 \\
\hline Pu239/240 & $8.9 E+12$ & 240.3 & $24390 y$ & 1000 & 2000 \\
\hline Pu241 & $7.4 E+12$ & 199.8 & $13.2 y$ & 100 & 200 \\
\hline Am241 & $1.5 E+13$ & $\overline{405}$ & $433 y$ & 1000 & 2000 \\
\hline $\mathrm{Am} 242 \mathrm{~m}$ & $2.2 E+10$ & 0.594 & $152 y$ & 100 & 200 \\
\hline Am243 & $8.1 E+09$ & 0.2187 & $7950 y$ & 100 & 200 \\
\hline $\mathrm{Cm} 242$ & $1.7 E+10$ & 0.459 & $162.5 d$ & 1 & 2 \\
\hline $\mathrm{Cm} 244$ & $3.7 E+10$ & 0.999 & $18.1 y$ & 10 & 20 \\
\hline \multicolumn{6}{|c|}{\begin{tabular}{|l|l|l|} 
& TOTAL & 37242 \\
\end{tabular}} \\
\hline \multicolumn{6}{|c|}{$\begin{array}{l}\text { The matrix shown on page } 5 \text { and the discussion of column } 7 \text { starts on page } 6 \text { (ref } 10 \text { ) } \\
\text { were consulted to determine the 'Applicable Multiplying Factor' for each radionuclide in } \\
\text { Tank S-101, based on the half-lives (column } 4 \text { ) and Curie contents (column } 3 \text { ) of the } \\
\text { radionuclides. The multiplying factor was then multiplied by } 2 \text { (shown in column } 6 \text { ) to } \\
\text { assign a score to each radionuclide. The last entry in column } 6 \text { (the bottom right } \\
\text { corner of the table) demonstrates the total score assigned to Tank S-101 by the } \\
\text { addition each individual radionuclide scores for that tank. The calculations were } \\
\text { performed using an EXCEL spreadsheet. }\end{array}$} \\
\hline
\end{tabular}


TABLE C-2 (Continued)

TANK 241-S-101 - CONSEQUENCE SCORE

Chemical Hazard Scope

Chemical Hazard Rating

Radiological Hazard Score

Radiological Hazard Rating

Ranking Factors Total

Ranking Factor Divided by Liquid (Kgal)

\subsection{E8}

3

37242

3

$(3+3) \times 100=600$

$600 \div 90=6.67$ 
TABLE C-3

RECOMMENDED PUMPING SEQUENCE - BASED ON ENTIRE TANK CONTENT

\begin{tabular}{|c|c|c|c|c|c|}
\hline FARM & $\begin{array}{l}\text { SST (IN ORDER } \\
\text { OF PUMPING } \\
\text { PRIORITY) }\end{array}$ & $\begin{array}{c}\text { RISK DECREASE PER } \\
\text { FARM }\end{array}$ & $\begin{array}{c}\text { ESTIMATED INTERIM } \\
\text { STABILIZATION TIME } \\
\text { (DAYS) }\end{array}$ & $\begin{array}{l}\text { INTERIM } \\
\text { STABILIZATION } \\
\text { START DATE }\end{array}$ & $\begin{array}{c}\text { INTERIM } \\
\text { STABILIZATION } \\
\text { COMPLETION } \\
\text { DATE }\end{array}$ \\
\hline & & $\begin{array}{l}6563 \text { (TOTAL from } \\
\text { TABLE B-6) }\end{array}$ & & $10 / 1 / 93$ & \\
\hline$T$ & $T-111$ & 89.33 & 317 & $5 / 17 / 94$ & $3 / 30 / 95$ \\
\hline BY & $\begin{array}{l}\text { BY-109, } \\
\text { BY-102. }\end{array}$ & 623.39 & 215 & $5 / 30 / 94$ & $12 / 31 / 94$ \\
\hline C & $\begin{array}{c}\text { C-107, C-102, } \\
\text { C-110 }\end{array}$ & 568.30 & 92 & $9 / 30 / 94$ & $12 / 31 / 94$ \\
\hline BY & $\begin{array}{l}\text { BY-106, } \\
\text { BY-105, } \\
\text { BY-103 }\end{array}$ & 1400.99 & 546 & 6/1/95 & $11 / 28 / 96$ \\
\hline $8 x$ & $B X-108$ & 600.00 & 15 & $6 / 1 / 95$ & $6 / 16 / 95$ \\
\hline $\begin{array}{c}\text { S ( non-WATCH } \\
\text { LIST TANKS) }\end{array}$ & $\begin{array}{c}\text { S-107, S-103, } \\
\text { S-109, s-101, } \\
\text { s-108, s-110, } \\
\text { s-106 }\end{array}$ & 688.08 & 414 & $1 / 2 / 96$ & $2 / 19 / 97$ \\
\hline$T$ & $\begin{array}{c}T-104, T-110 \\
T-107\end{array}$ & 311.93 & 143 & $5 / 22 / 96$ & $10 / 12 / 98$ \\
\hline c & C.103 & 199.10 & 133 & $8 / 30 / 98$ & $11 / 10 / 98$ \\
\hline$u$ & $\begin{array}{l}\text { U-102, U-111, } \\
\text { U-108, U-107, } \\
\text { U-108, U-109, } \\
\text { U-103, U-105 }\end{array}$ & 651.15 & 408 & $7 / 26 / 96$ & $9 / 5 / 97$ \\
\hline $\begin{array}{c}\text { S ( WATCH LIST } \\
\text { TANKS) }\end{array}$ & $\begin{array}{c}S-102, s-112 \\
S-111\end{array}$ & 346.63 & 531 & $10 / 24 / 96$ & $4 / 8 / 98$ \\
\hline A & A-101 & 125.73 & 996 & $12 / 27 / 96$ & $9 / 19 / 99$ \\
\hline$A x$ & $A X-101$ & 125.65 & 761 & $4 / 22 / 97$ & $5 / 23 / 99$ \\
\hline$s x$ & $\begin{array}{l}s \times 108, s \times 102, \\
s \times 101, s \times 103, \\
s \times 104, s \times 105\end{array}$ & 773.65 & 609 & $8 / 8 / 97$ & 4/9/99 \\
\hline
\end{tabular}

To create the Recommended Approach Schedule certain assumptions were made:

i) SST 241-BY-102 \& 241-8Y-109 preparation for pumping will be completed by 5/30/94

ii) only 3 farms are to be prepared for pumping at the same time (with the exception of 241-T-111). 
FIGURE C-3

RISK EVALUATION

RECOMMENDED PUMPING SEQUENCE

BASED ON ENTIRE TANK CONTENT

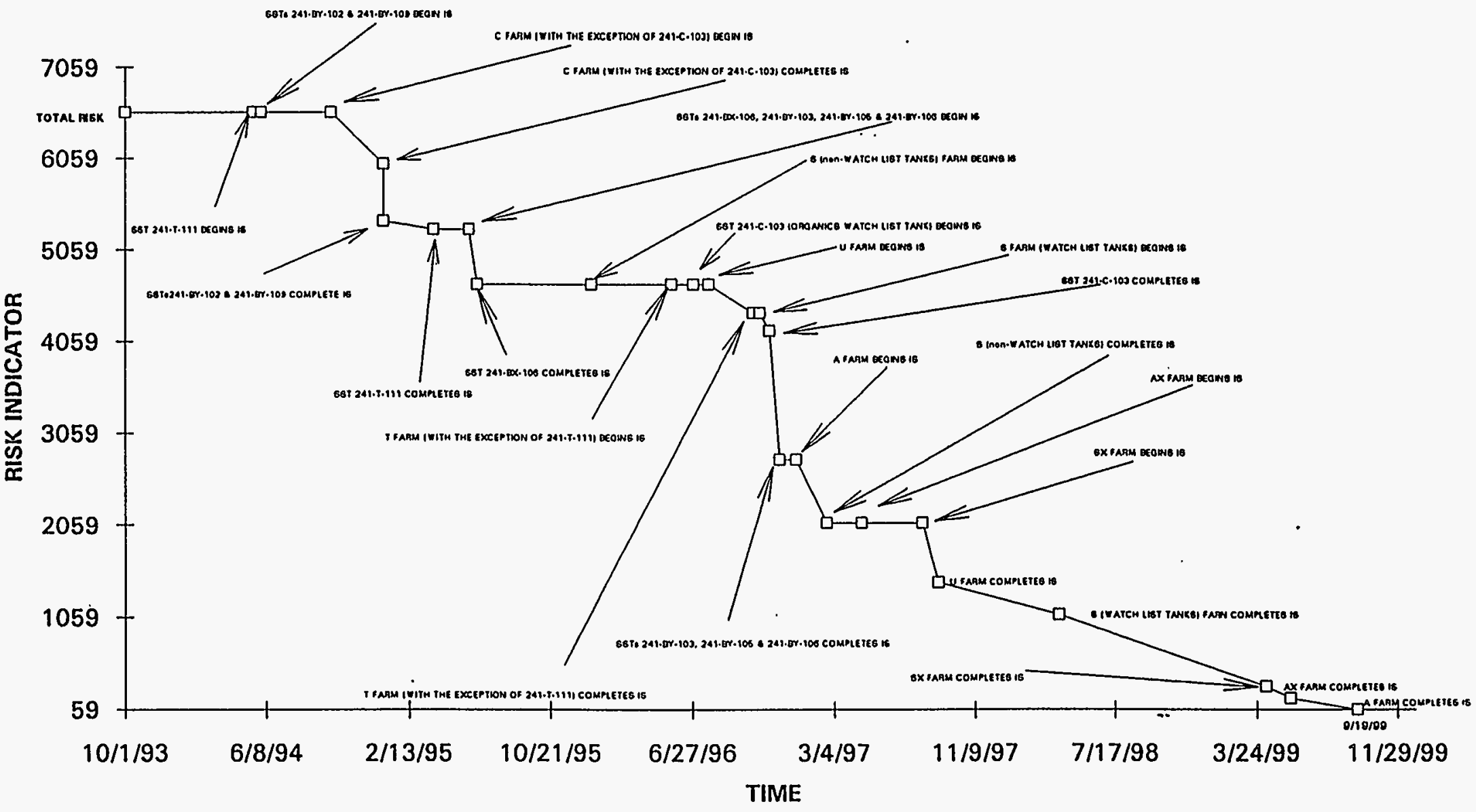

IS = INTERIM STABILIZATION 
TABLE C-4

TPA MILESTONE PUMPING SEQUENCE BASED ON ENTIRE TANK CONTENT

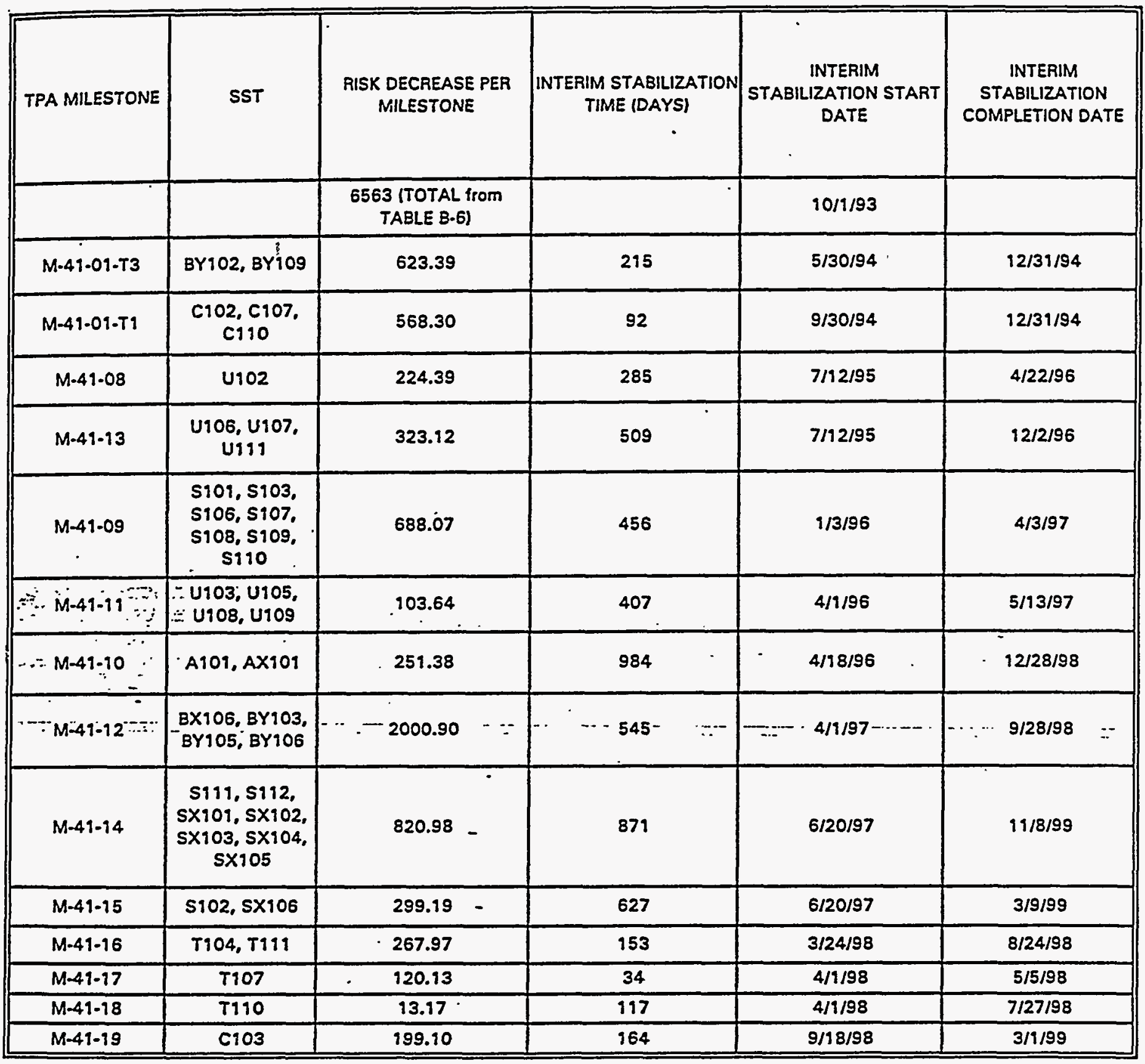


WHC-SD-WM-ES-345, Rev 0

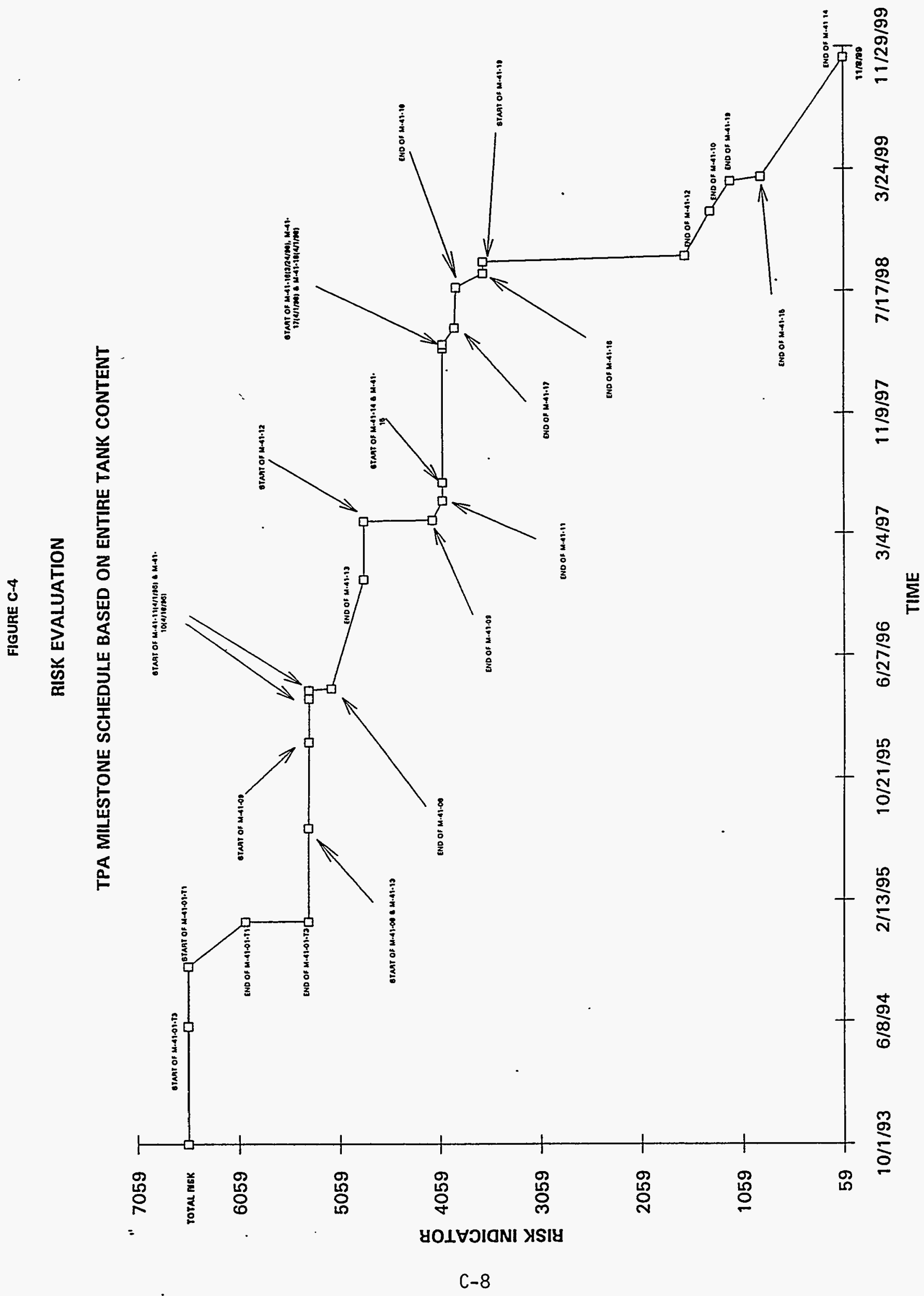




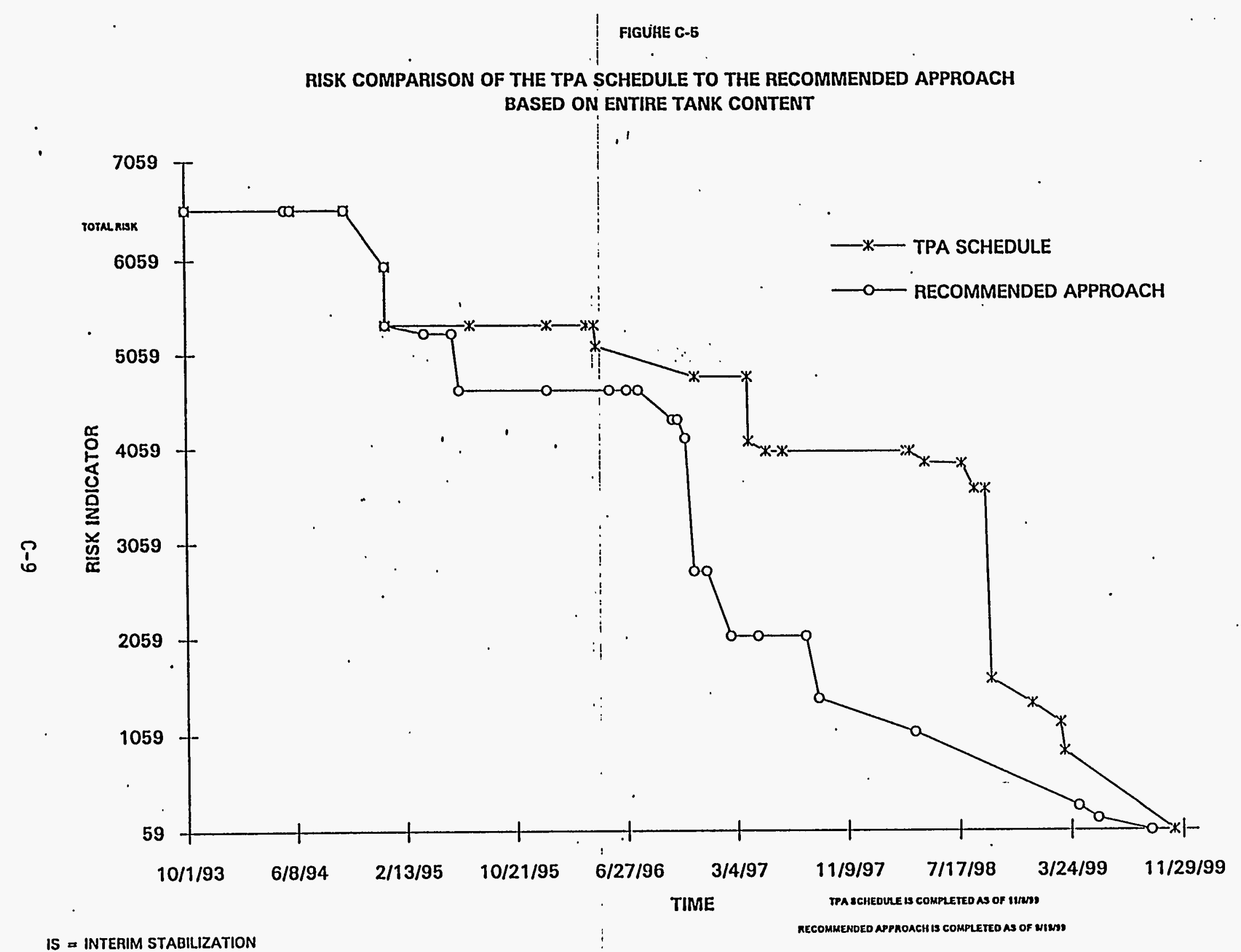

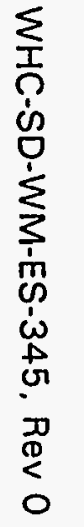

